\title{
ATM-Dependent Phosphorylation of MEF2D Promotes Neuronal Survival after DNA Damage
}

\author{
Shing Fai Chan, ${ }^{1}$ Sam Sances, ${ }^{1}$ Laurence M. Brill, ${ }^{2}$ Shu-ichi Okamoto, ${ }^{1}$ Rameez Zaidi, ${ }^{1}$ Scott R. McKercher, ${ }^{1}$ \\ Mohd W. Akhtar, ${ }^{1}$ Nobuki Nakanishi, ${ }^{1}$ and Stuart A. Lipton ${ }^{1}$ \\ ${ }^{1}$ Del E. Webb Center for Neuroscience, Aging, and Stem Cell Research, and 2Proteomics Facility, Sanford-Burnham Medical Research Institute, La Jolla, \\ California 92037
}

\begin{abstract}
Mutations in the ataxia telangiectasia mutated (ATM) gene, which encodes a kinase critical for the normal DNA damage response, cause the neurodegenerative disorder ataxia-telangiectasia (AT). The substrates of ATM in the brain are poorly understood. Here we demonstrate that ATM phosphorylates and activates the transcription factor myocyte enhancer factor 2D (MEF2D), which plays a critical role in promoting survival of cerebellar granule cells. ATM associates with MEF2D after DNA damage and phosphorylates the transcription factor at four ATM consensus sites. Knockdown of endogenous MEF2D with a short-hairpin RNA (shRNA) increases sensitivity to etoposide-induced DNA damage and neuronal cell death. Interestingly, substitution of endogenous MEF2D with an shRNA-resistant phosphomimetic MEF2D mutant protects cerebellar granule cells from cell death after DNA damage, whereas an shRNA-resistant nonphosphorylatable MEF2D mutant does not. In vivo, cerebella in Mef2d knock-out mice manifest increased susceptibility to DNA damage. Together, our results show that MEF2D is a substrate for phosphorylation by ATM, thus promoting survival in response to DNA damage. Moreover, dysregulation of the ATM-MEF2D pathway may contribute to neurodegeneration in AT.
\end{abstract}

Key words: ataxia telangiectasia; ATM; DNA damage; MEF2D; neuronal survival; phosphorylation

\section{Introduction}

Individuals with the autosomal recessive disorder ataxia telangiectasia (AT) are characterized by immune deficiency, predisposition to cancer, hypersensitivity to ionizing radiation (IR), progressive mental retardation, and, most noticeably, cerebellar degeneration with a resulting ataxic gait disorder (Lavin et al., 2007). Presently, there is no cure for AT, which results from dysfunction of AT mutated (ATM), a $370 \mathrm{kDa}$ protein that manifests protein kinase activity and a carboxyl terminal domain similar to the phosphatidylinositol-3-kinase (PI3K) family (Rotman and Shiloh, 1998).

ATM plays a role in cellular responses to DNA damage, such as activating DNA repair, triggering cell cycle checkpoints, and coordinating the balance between cell survival and apoptosis (Kamer et al., 2005; Zinkel et al., 2005; Biton et al., 2006; Wu et al., 2006). ATM is activated by autophosphorylation in response to DNA double-strand breaks (DSBs) and oxidative stress (Bakken-

\footnotetext{
Received May 22, 2012; revised Jan. 15, 2014; accepted Feb. 11, 2014

Author contributions: S.F.C. designed research; S.F.C., S.S., L.M.B., R.Z., and M.W.A. performed research; S.-i.0. and R.Z. contributed unpublished reagents/analytic tools; S.F.C., L.M.B., S.-i.O., M.W.A., N.N., and S.A.L. analyzed data; S.F.C., L.M.B., S.R.M., N.N., and S.A.L. wrote the paper.

This work was supported by the Ataxia Telangiectasia Children's Project and National Institutes of Health Grants R01 EY05477, P01 HD29587, P30 ES016738, and P30 NS076411. We thank Tomohiro Nakamura and Juan PiñaCrespo (Sanford-Burnham) for helpful discussions; Eric N. Olson (University of Texas, Southwestern Medical Center) for providing Mef2d knock-out mice; and G. Nuñez (University of Michigan) for Bcl-xL promoter constructs.

The authors declare no competing financial interests.

Correspondence should be addressed to Dr. Stuart A. Lipton, Del E. Webb Center for Neuroscience, Aging, and Stem Cell Research, Sanford-Burnham Medical Research Institute, 10901 North Torrey Pines Road, La Jolla, CA 92037. E-mail: slipton@sanfordburnham.org.

DOI:10.1523/JNEUROSCI.2510-12.2014

Copyright $\odot 2014$ the authors $\quad 0270-6474 / 14 / 344640-14 \$ 15.00 / 0$
}

ist and Kastan, 2003; Kozlov et al., 2006; Guo et al., 2010). DSBs, the most severe form of DNA damage, are generated by exogenous agents or endogenously generated reactive oxygen species (ROS) (Khanna and Jackson, 2001). ATM phosphorylates serine or threonine residues that are followed by glutamine (representing the SQ/TQ motif) (Kim et al., 1999; O’Neil et al., 2000). Biochemical and genetic analyses have identified numerous substrates for ATM, most of which are related to regulation of cell cycle checkpoints or the development of cancer (Shiloh, 2003). However, the most prevalent feature of AT is progressive neurodegeneration, which has been postulated to result from a defective DNA damage response, decreased survival signaling, or increased oxidative stress (Rotman and Shiloh, 1997; Barzilai et al., 2002; Uziel et al., 2003). Nevertheless, little is known about potential ATM substrates in the CNS.

Analyzing sequence information, we identified four potential ATM consensus phosphorylation motifs in the neuronal prosurvival transcription factor, myocyte enhancer factor 2D (MEF2D) (see Fig. 1A). MEF2, a member of the MADS (MCM1-agamousdeficiens-serum response factor) domain-containing transcription factor family, is highly expressed in neurons and a key determinant of neuronal survival, differentiation, and synaptic plasticity (McKinsey et al., 2002; Flavell and Greenberg, 2008). MEF2 family members A-D bind as homodimers and heterodimers to the DNA consensus sequence CTA $(\mathrm{A} / \mathrm{T})_{4} \mathrm{TA}(\mathrm{G} / \mathrm{A})$ (Naya and Olson, 1999). MEF2D is the predominant isoform in the cerebellum, which is most affected in AT (Leifer et al., 1993; Lin et al., 1996). Although many signal transduction pathways promote MEF2 phosphorylation, thus modulating the prosurvival and neurogenic functions of MEF2 in the CNS, a signaling 
pathway that regulates MEF2-dependent survival in response to DNA damage has not yet been defined.

We report that, in response to DNA damage, ATM associates with MEF2D and enhances its activity via phosphorylation. Short-hairpin RNA (shRNA) knockdown of MEF2D increases cellular sensitivity to etoposide-induced neuronal cell death. Substitution of endogenous MEF2D with phosphomimetic MEF2D mutant protects cerebellar granule cells from cell death after DNA damage, whereas nonphosphorylatable MEF2D mutant does not. Moreover, cerebellar granule cells in Mef2d knockout mice manifest hypersensitivity to DNA damage. Together, these results suggest that defects in activation of ATM-MEF2D survival signaling in response to DNA damage may contribute to AT neurodegeneration.

\section{Materials and Methods}

Atm and Mef2d knock-out mice and genotyping. Mice deficient in ATM (Barlow et al., 1996) were purchased from The Jackson Laboratory. Mef2d knock-out mice were provided by E.N. Olson (Department of Molecular Biology, University of Texas Southwestern Medical Center, Dallas). Atm and Mef2d knock-out mice of both sexes were used for experiments, and wild-type (wt) littermates were used as controls. Generation of animals and PCR genotyping were performed as previously described (Barlow et al., 1996; Kim et al., 2008).

cDNA constructs and plasmids. Expression plasmids for the GAL4 DNA binding domain [GAL4(DBD)] fused with the transactivation domains of MEF2D (amino acids 87-506) and His-tagged full-length MEF2D were constructed as previously described (Han et al., 1997). Expression plasmids for wt- and kinase dead (kd)-ATM were kindly provided by M.B. Kastan (St. Jude's Children's Research Hospital, Memphis) (Bakkenist and Kastan, 2003). The MEF2 dominant-negative construct (MEF2-DN) contains the DNA-binding domain of MEF2 but acts as a dominant-interfering form because of truncation of the transactivation domain was at amino acid residue 105 (the remainder of the sequence is replaced with a Flag tag) (Okamoto et al., 2000). The MEF2 constitutively active construct (MEF2-CA) contains a truncated version of the MEF2C transactivation domain and instead encodes a VP16 transactivation domain that is constitutively active (Okamoto et al., 2000). Expression plasmids containing cDNAs encoding human ATM or MEF2D were used as described previously (Breitbart et al., 1993; Okamoto et al., 2002; Bakkenist and Kastan, 2003).

In vitro immunocomplex kinase assays. In vitro immunocomplex kinase assays were performed as previously described (Ziv et al., 2000). Briefly, cell extracts from human embryonic kidney (HEK) 293T cells transfected with $10 \mu \mathrm{g}$ of wt- or kd-ATM cDNAs were prepared in modified TGN buffer (in mM) as follows: 50 Tris, $150 \mathrm{NaCl}, 1$ sodium fluoride, $1 \mathrm{Na}_{3} \mathrm{VO}_{4}$, 1 phenylmethylsulfonyl fluoride, $1 \%$ Tween 20 , and $0.3 \%$ Nonidet P- 40 , pH 7.5, with added protease inhibitor mixture from Roche Molecular Biochemicals, and phosphatase inhibitor mixture I and II from Sigma. Cleared supernatants were immunoprecipitated with an anti-Flag M2 antibody (Sigma) and protein A/G-agarose; the beads were washed with TGN buffer, followed by TGN buffer plus $0.5 \mathrm{M} \mathrm{LiCl}$. Two additional washes were then performed in kinase buffer (in $\mathrm{mM}$ ) as follows: $20 \mathrm{HEPES}, 50 \mathrm{NaCl}, 10 \mathrm{MgCl}_{2}, 1$ dithiothreitol, $10 \mathrm{MnCl}_{2}$, pH 7.5. The immunoprecipitants were resuspended in $50 \mu \mathrm{l}$ of kinase buffer containing $10 \mu \mathrm{Ci}$ of $\left[\gamma_{-}{ }^{32} \mathrm{P}\right] \mathrm{ATP}$, plus either $1 \mu \mathrm{g}$ of recombinant GST-p53 or His-tagged MEF2D fusion protein. Kinase reactions were conducted at $30^{\circ} \mathrm{C}$ for $20 \mathrm{~min}$ and stopped by the addition of SDS-PAGE loading buffer. Radiolabeled proteins were separated using SDS-PAGE and assessed with autoradiography. Transfection of kd-ATM cDNAs was used as a control in these experiments. Protein loading levels were determined by Coomassie Brilliant Blue staining.

Reporter gene assays. All luciferase assays were performed as previously described (Okamoto et al., 2000), using the Dual Luciferase Assay Kit (Promega), according to the manufacturer's instructions. For GAL4dependent luciferase reporter gene assays, the GAL4-responsive plasmid pG5E1bLuc, which contains five GAL4 sites cloned upstream of a mini- mal promoter driving a luciferase (luc) gene, was used as previously described (Gupta et al., 1995; Han et al., 1997). The reporter plasmids pG5E1bLuc and Renilla were cotransfected into cells with a construct expressing the GAL4-DNA binding domain fused to MEF2D, along with an expression vector encoding wt- or kd-ATM. Cells were transiently transfected with $3 \mu \mathrm{g}$ of total plasmid DNA using Lipofectamine 2000 reagent (Invitrogen). Renilla expression plasmids were used to control for transfection efficiency. The total amount of DNA for each transfection was kept constant by using the empty vector pcDNA3. After $24 \mathrm{~h}$, cell extracts were prepared, and luciferase activities were measured according to the Promega protocol. The basal luciferase activity of untreated cells that were transfected with wt-ATM or scrambled shRNA was arbitrarily set equal to 1 , and all other values were normalized to this reference point. To measure endogenous MEF2 activity in cells, MEF2-dependent luciferase reporter gene assays were performed as previously described (Okamoto et al., 2000). Bcl-xL-promoter luciferase reporter was provided by Gabriel Nuñez (Grillot et al., 1997). For serum induction, NIH $3 \mathrm{~T} 3$ cells were serum starved in $0.5 \%$ calf serum for $30 \mathrm{~h}$ after transfection. The starved cells were then treated with $20 \%$ serum for $2 \mathrm{~h}$ before collection of cell lysates for luciferase assays.

DNA-damaging agents, kinase inhibitor, and ATM small-molecule inhibitor. Cells were exposed to etoposide (10 $\mu \mathrm{M}$ for $2 \mathrm{~h}$ ), staurosporine $(0.1 \mu \mathrm{M}$ for $2 \mathrm{~h})$, or ultraviolet light $\left(10 \mathrm{~J} / \mathrm{m}^{2}\right)$. Cells or animals at postnatal day (P) 18 or adult were irradiated at 10 Gy using a Gammacell 40 Exactor (MDS Nordion). For in vivo experiments, the animal's head (and thus the brain) was exposed to irradiation, and the remainder of the body was protected by a lead shield. For experiments in vitro, cells in some cultures were preincubated with the ATM inhibitor, KU55933 (2morpholin-4-yl-6-thianthren-1-yl-pyran-4-one) for $1 \mathrm{~h}$ before exposure to 10 Gy irradiation (Biton et al., 2006). KU55933 was a kind gift from KuDOS Pharmaceuticals.

Assessment of apoptosis and TUNEL staining. To assess apoptosis, the percentage of EGFP-positive cells with fragmented and condensed nuclei was quantified using epifluorescence microscopy. Hoechst dye 33342 was used to label nuclei. The animals were subjected to irradiation at P18, and the brains were analyzed after $16 \mathrm{~h}$. For TUNEL assays, we processed coronal sections (12 $\mu \mathrm{m}$ thick) from P18 brains using the In Situ Cell Death Detection Kit, TMR Red (Roche) according to the manufacturer's instructions. We quantified the total number of TUNEL-positive nuclei per unit area $\left(\mathrm{mm}^{2}\right)$ of the cerebellar folia in Mef2d knock-out mice compared with wt mice.

RNA interference. psiSTRIKE-hMGFP vectors expressing shRNAs targeting ATM or MEF2D (or scrambled controls representing sequences not found in the mouse, human, or rat genome databases) were constructed according to the manufacturer's instructions (Promega). We checked the efficiency of knockdown by immunocytochemistry performed $3 \mathrm{~d}$ after transfection. The following target sequence was used to generate shRNA against MEF2D: shRNA-MEF2D-436, 5'-GTGCCC GTGTCCAATCAGA-3' (the number 436 refers to the target sequence of the MEF2D cDNA).

The following target sequences were used to generate shRNAs against ATM and scrambled shRNA: (1) shRNA-ATM-1, 5'-GCTGAGACAA ATAATGTCT-3'; (2) shRNA-ATM-2, 5' -AGAATTCTGGAAGTTATT-3'; and (3) scrambled shRNA: 5'-GCCTATTTCCCATGATTCC-3'.

Cerebellar brain slices for mitochondrial superoxide (MitoSOX) staining. Mice were decapitated and cerebella rapidly dissected. Cerebellar brain slices (150 $\mu \mathrm{m}$ in thickness) were collected in ice-cold dissection buffer (in mM) as follows: 212 sucrose, $3 \mathrm{KCl}, 5 \mathrm{MgCl}_{2}, 0.5 \mathrm{CaCl}_{2}, 1 \mathrm{NaH}_{2} \mathrm{PO}_{4}$, $26 \mathrm{NaHCO}_{3}$, and 10 glucose. Brain slices were incubated at $30^{\circ} \mathrm{C}$ for $1 \mathrm{~h}$ in ACSF containing the following (in $\mathrm{mm}$ ): $124 \mathrm{NaCl}, 5 \mathrm{KCl}, 26 \mathrm{NaHCO}_{3}$, $1.25 \mathrm{NaH}_{2} \mathrm{PO}_{4}, 2 \mathrm{CaCl}_{2}, 1 \mathrm{MgCl}_{2}$, and 10 glucose. ACSF and dissection buffer were oxygenated with $95 \% \mathrm{O}_{2} / 5 \% \mathrm{CO}_{2}$. To measure superoxide production by mitochondria, cerebellar slices were incubated in $1.25 \mu \mathrm{M}$ MitoSOX (Invitrogen) for $10 \mathrm{~min}$ at room temperature before imaging. MitoSOX penetrates into cells rapidly and selectively targets mitochondria. Once in the mitochondria, MitoSOX is oxidized by superoxide to display a red fluorescence.

Preparation of primary cerebellar granule cell cultures. Primary cultures of cerebellar granule cells were obtained by mechanical and enzymatic 
dissociation of cerebella obtained from both sexes of P6 or P7 Sprague Dawley rats, Atm wt or knock-out mice, and Mef2d wt or knock-out mice, as previously described (Levi et al., 1984). Briefly, animals were decapitated and cerebella were isolated and immersed in ice-cold HIB solution ( $120 \mathrm{~mm} \mathrm{NaCl}, 5 \mathrm{~mm} \mathrm{KCl}, 25 \mathrm{~mm}$ HEPES, and $9.1 \mathrm{~mm}$ glucose). Dissociated cells were suspended in basal medium with Eagle's salts plus $25 \mathrm{~mm} \mathrm{KCl,} 2 \mathrm{~mm}$ glutamine, and antibiotic (penicillin and streptomycin), and plated on poly-L-lysine coated dishes. At plating, $10 \%$ heatinactivated FCS was added to the medium. After 36-48 h, $10 \mu \mathrm{M}$ cytosine arabinoside was added to prevent non-neuronal cell replication. Thereafter, the medium was changed every $2 \mathrm{~d}$ until the cells were used for experiments, generally after $7-10 \mathrm{~d}$ in vitro (DIV). We used rat cerebellar granule cells to examine the effects of DNA damage on cell viability after knockdown of endogenous MEF2D expression (see Fig. 5A, C); mouse cerebellar granule cells were used in other experiments because of the availability of $M e f 2 d$ knock-out mice and wt littermates.

Preparation of recombinant His-tagged MEF2D fusion proteins. Escherichia coli $\mathrm{BL} 21$ (DE3) was transformed with the vector $\mathrm{pETM} 1$ containing cDNAs encoding MEF2D. The transformed bacteria were grown at $37^{\circ} \mathrm{C}$ in LB broth until the absorbance at $600 \mathrm{~nm}\left(A_{600}\right)$ reached 0.5 , at which time isopropyl- $\beta$-D-thiogalactopyranoside was added at a final concentration of $1 \mathrm{~mm}$ for $5 \mathrm{~h}$. Cells were collected by centrifugation at $8000 \times g$ for $10 \mathrm{~min}$, and the bacterial pellet was resuspended in $10 \mathrm{ml}$ of buffer A (30 mm NaCl, 10 mm EDTA, 20 mm Tris-HCl, 2 mm phenylmethylsulfonyl fluoride) for every $100 \mathrm{ml}$ of original bacterial culture. Cell suspension was sonicated and cellular debris removed by centrifugation at $10,000 \times g$ for $30 \mathrm{~min}$. Recombinant proteins from the cleared lysate were purified using a Ni-nitrilotriacetic acid purification system (QIAGEN).

Immunocytochemistry. Cells were fixed with $4 \%$ PFA for $10 \mathrm{~min}$ at room temperature and then washed three times in PBS, permeabilized with $0.5 \%$ Triton $\mathrm{X}-100$ for $5 \mathrm{~min}$, and washed three additional times. Nonspecific antibody binding was minimized by incubation in blocking solution (10\% goat serum in PBS) for $1 \mathrm{~h}$ at room temperature. Cells were incubated overnight at $4^{\circ} \mathrm{C}$ with primary antibodies against MEF2D (BD Transduction Laboratories) or phospho-(Ser/Thr) ATM/ATR substrates (phospho-SQ/TQ substrate antibody from Cell Signaling Technology). After washing, cells were incubated with anti-mouse or anti-rabbit antibodies conjugated to FITC or Alexa-498/594 for $1 \mathrm{~h}$ at room temperature, and then with Hoechst 33342 dye $(1 \mu \mathrm{g} / \mathrm{ml})$ to fluorescently stain nuclei. Immunostaining for ATM was performed as previously described (Wilson and Bianchi, 1990). Briefly, after chemical crosslinking, cells were treated with PBS containing 1\% SDS for 5 min. Cells were then incubated with a primary antibody against ATM (Abcam) overnight at $4^{\circ} \mathrm{C}$. Control experiments with secondary antibody alone were routinely performed and produced no detectable immunofluorescence signal.

Immunoprecipitation. Cell lysates of HEK293T were prepared in NP40 or RIPA buffer with a protease inhibitor mixture (Roche Molecular Biochemicals) and phosphatase inhibitor mixture I and II (Sigma), and then immunoprecipitated by incubating at $4^{\circ} \mathrm{C}$ for 90 min with protein $\mathrm{A} / \mathrm{G}-$ agarose (1:1 slurry in NP40 or RIPA buffer). After this preclearing step, supernatants were centrifuged at $1000 \times g$ for $3 \mathrm{~min}$ at $4^{\circ} \mathrm{C}$. Primary antibody was added at $10 \mu \mathrm{g} / \mathrm{ml}$ and incubated and rocked for $2 \mathrm{~h}$ at $4^{\circ} \mathrm{C}$. Protein A/G-agarose (1:1 slurry in NP40 or RIPA buffer) was added, and the mixture was incubated with rocking for $2 \mathrm{~h}$ at $4^{\circ} \mathrm{C}$. After this incubation, the agarose was pelleted by centrifugation at $1000 \times g$ for $3 \mathrm{~min}$ at $4^{\circ} \mathrm{C}$ and washed three times with NP40 or RIPA buffer. To dephosphorylate samples, alkaline phosphatase $\left(10 \mathrm{U}\right.$ at $37^{\circ} \mathrm{C}$ for $1 \mathrm{~h}$ ) was added after immunoprecipitation. After the final wash, the agarose was resuspended and boiled in $30 \mu \mathrm{l}$ of $2 \times$ sample loading buffer at $100^{\circ} \mathrm{C}$ for $7 \mathrm{~min}$. Immunoprecipitation samples were then analyzed by SDS-PAGE and Western blotting.

Western blotting. Proteins were transferred onto PVDF membranes and then blocked with $5 \%$ nonfat dried milk in Tris-buffered saline containing $0.05 \%$ Tween 20, pH 7.6 (TBST) for $1 \mathrm{~h}$ at room temperature. PVDF membranes were incubated with primary antibody in TBST containing $1 \%$ nonfat milk overnight at $4^{\circ} \mathrm{C}$. ATM-phosphorylated MEF2 proteins were detected with phospho-SQ/TQ substrate antibody (Cell
Signaling Technology). The antibody against MEF2D was from BD Transduction Laboratories, anti-Bcl-xL was from Cell Signaling Technology, anti-actin was from Millipore, and the anti-V5 antibody was from Millipore Bioscience Research Reagents. Immunoreactive proteins were detected using anti-rabbit or anti-mouse antibodies coupled to HRP (GE Healthcare) and visualized with enhanced chemiluminescence using an ECL kit (GE Healthcare). The films were scanned into Adobe Photoshop with Epson optical scanner and stored as grayscale images in TIFF file format. The intensity of labeling was quantified by measuring the gray value of the pixels contained in a rectangular area matching the bands of interest. To ensure equal loading, protein concentrations were determined using the BCA Protein Assay (Pierce).

Site-directed mutagenesis. Point mutations were introduced into wt MEF2D expression vector using the QuikChange Site-Directed Mutagenesis Kit (Stratagene). The following primers were used to generate shRNAresistant MEF2D cDNAs, with silent mutations underlined and italicized as follows: (1) shRNA-resistant MEF2D-1: 5'-GCCTGTCACGGTGCCAGT GTCCAATCAGAGC-3'; (2) shRNA-resistant MEF2D-2: 5'-GCCTGTC ACGGTGCCAGTCTCCAATCAGAGC-3'; (3) shRNA-resistant MEF2D-3: 5' -GCCTGTCACGGTCCCAGTCTCCAATCAGAGC-3'; (4) shRNAresistant MEF2D-4: 5'-ACGGTCCCAGTCTCAAACCAGAGCTCACTG-3'; and (5) shRNA-resistant MEF2D-5: 5'-GTCCCAGTCTCAAACCAAAGCTC ACTGCAG-3'.

The following primers were used to generate single point mutations in MEF2D cDNAs. For mutation of threonine 259 to alanine T259A: $5^{\prime}-$ ACCTACCCACAGCGCCCAGCTTGGAGCC-3'. For mutation of serine275 toalanineS275A:5'-CGAGTCATCACTGCCCAGGCAGGAAAG GGG-3'. For mutation of serine 294 to alanine S294A: 5'-CGCCTT GGGGTCGCCCAGTCTACTCATTCG-3'. For mutation of serine 314 to alanine S314A: 5'-AACGCCGAGTTTACTCGCCCAGGGCCTC CCC- $3^{\prime}$. A combination of the above primers was used to generate quadruple MEF2D mutants.

The following primers were used to generate the phosphomimetic MEF2D mutants. For mutation of threonine 259, serine 275, serine 294, and serine 314 into aspartic acid, respectively: (1) 5'-ACCTACCCA CAGCGACCAGCTTGGAGCC-3'; (2) 5'-CGAGTCATCACTGACCAGG CAGGAAAGGGG-3'; (3) 5'-CGCCTTGGGGTCGACCAGTCTACTC ATTCG-3'; and (4) 5'-GCCGAGTTTACTCGACCAGGGCCTCCCC-3'.

$q R T-P C R$. Total RNA was extracted from wt and $M e f 2 d^{-1-}$ mice using the PureLink RNA Mini Kit (Invitrogen). Approximately $1 \mu \mathrm{g}$ of total RNA was reverse transcribed in a total volume of $20 \mu \mathrm{l}$ using SuperScript III (Invitrogen) according to the manufacturer's instructions. The resulting cDNA was diluted 1:10. qRT-PCR was performed using SYBR Green (Invitrogen) for detection of fluorescence during amplification. All primers were designed with annealing temperatures of $58^{\circ} \mathrm{C}-62^{\circ} \mathrm{C}$. All genes were amplified on a Mx3000P real-time PCR system (Stratagene) according to the manufacturer's instructions. We used the following conditions: 1 cycle for $10 \mathrm{~min}$ at $95^{\circ} \mathrm{C}$, followed by 40 cycles for $15 \mathrm{~s}$ at $95^{\circ} \mathrm{C}$ and $60 \mathrm{~s}$ at $60^{\circ} \mathrm{C}$. The primers used were as follows: GAPDH, $5^{\prime}-$ ACCACAGTCCATGCCATCAC- $3^{\prime}$ and $5^{\prime}$-TCCACCACCCTGTTGCT GTA-3'; Bcl-xL, 5' -AGGATACAGCTGGAGTCAG-3' and $5^{\prime}$-TCTCC TTGTCTACGCTTTCC-3'. We performed PCR amplification in triplicate with at least three separate analyses performed for each gene and checked for the presence of nonspecific PCR products and primer dimers by melting curve analysis after each run. The qRT-PCR results, recorded as threshold cycle numbers $\left(\mathrm{C}_{\mathrm{t}}\right)$, were normalized using GAPDH as an internal control and analyzed using the comparative $C_{t}$ method (Livak and Schmittgen, 2001; Schmittgen and Livak, 2008).

Protein digestion and $\mathrm{TiO}_{2}$-based phosphopeptide enrichment. Proteins were reduced with dithiothreitol, alkylated with indoleacetamide (both from Sigma-Aldrich), and digested with modified sequencing grade tryp$\sin$ (Promega) using standard procedures. Peptides were desalted using a peptide microtrap (Bruker-Michrom). Desalting was accomplished using $400 \mu \mathrm{l} 95: 5$ solvents $\mathrm{A}: \mathrm{B}$ (solvent $\mathrm{A}=0.1 \%$ formic acid, solvent $\mathrm{B}=$ $100 \%$ acetonitrile) at $100 \mu \mathrm{l} / \mathrm{min}$. Desalted peptides were eluted from the microtrap with $200 \mu \mathrm{l} 70: 30$ solvents A:B at $100 \mu \mathrm{l} / \mathrm{min}$ and dried in a speed vac. The volume of each solvent for phosphopeptide enrichment was $200 \mu \mathrm{l}$. A total of $40 \mu \mathrm{l}$ of $\mathrm{TiO}_{2}$ beads (GL Sciences, $5020-75000$ ) as a $10 \mathrm{mg} / \mathrm{ml}$ slurry in loading solvent, plus $160 \mu \mathrm{l}$ loading solvent was 
A

B

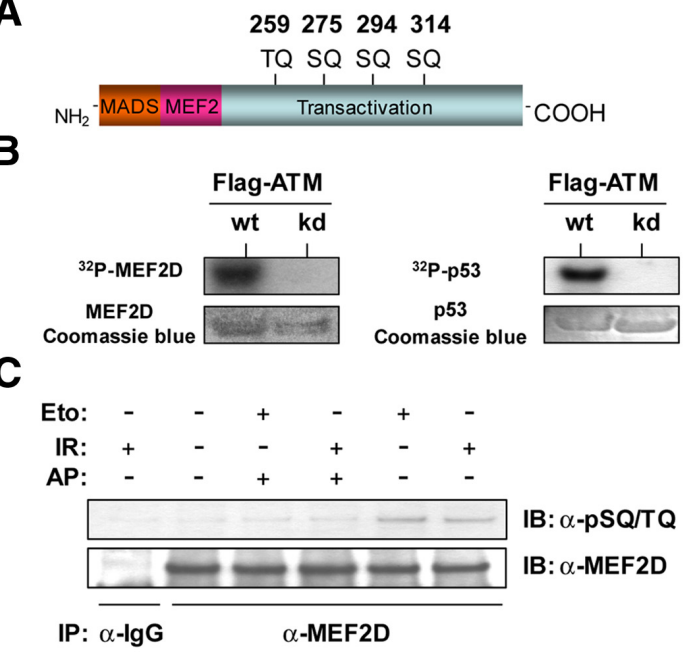

D

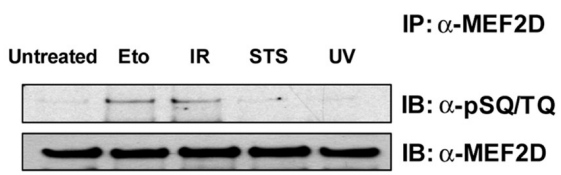

$\mathbf{E}$

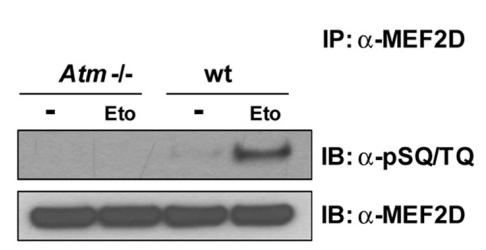

$\mathbf{F}$

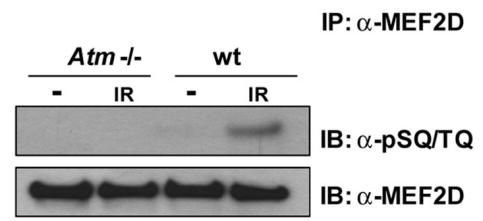

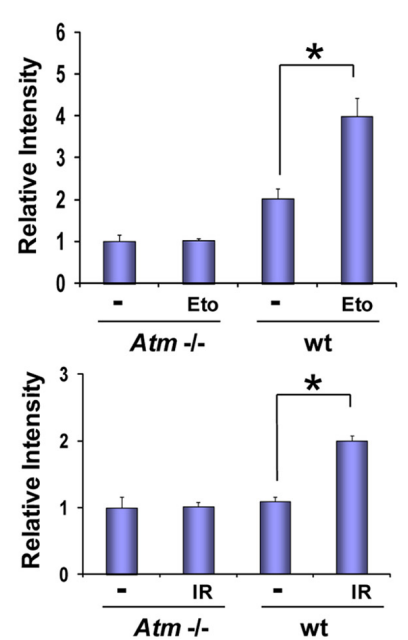

Figure 1. ATM phosphorylates MEF2D. A, MEF2D contains conserved domains for DNA binding (at the N terminus), dimerization, and transactivation (at the ( terminus). Vertical lines indicate potential ATM-phosphorylatable sites in MEF2D. B, ATM phosphorylates MEF2D in vitro. Cell extracts from HEK293T cells transfected with wt- or kd-ATM CDNAs were immunoprecipitated with anti-Flag M2 antibody. Immunoprecipitants were then incubated with $\gamma-{ }^{32} \mathrm{P}$ ATP and recombinant GST-p53 or His-tagged MEF2D fusion proteins. C, DNA-damaging agents increase MEF2D phosphorylation in cerebellar granule cells. Cells were exposed to IR, etoposide (Eto), or control conditions. Alkaline phosphatase (AP) was added after immunoprecipitation (IP) in the indicated samples. D, DNA-damaging agents that induce DSBs trigger MEF2D phosphorylation in cultured cerebellar granule cells. Cells were exposed to IR, Eto, staurosporine (STS), UV, or control conditions. $\boldsymbol{E}$, MEF2D phosphorylation was detected in wt-ATM cells but not in ATM-deficient cells. Cerebellar granule cells cultured from wt and knock-out mice (Atm ${ }^{-1-}$ ) were exposed to etoposide (Eto) or control conditions. Left, ATM-phosphorylated MEF2D proteins were detected by immunoblotting (IB) with anti-phospho-SQ/TQ substrate antibody; total MEF2D protein expression was detected by immunoblotting with anti-MEF2D antibody. Right, Densitometric analysis of immunoblots was performed, and the relative densitometric values are presented as mean \pm SEM ( $n=3$ independent experiments). ${ }^{*} p<$ 0.01 ( $t$ test with Bonferroni correction). Densitometric values of bands from untreated ATM-deficient cells were arbitrarily set equal to 1 , and other values were normalized to this reference point. $F$, Irradiation induced MEF2D phosphorylation in brains from wt mice but not from Atm knock-out mice. Adult brains of wt and Atm knock-out ( $\mathrm{Atm}^{-/-}$) mice were exposed in vivo to $10 \mathrm{~Gy}$ IR or control conditions (unexposed). Left, ATM-phosphorylated MEF2D proteins were detected by immunoblotting (IB) with anti-phospho-SQ/TQ substrate antibody; total MEF2D protein expression was detected by immunoblotting with anti-MEF2D antibody. Right, Densitometric analysis of immunoblots was performed, and the relative densitometric values are presented as mean \pm SEM $\left(n=3\right.$ independent experiments). ${ }^{*} p<0.01$ ( $t$ test with Bonferroni correction). Densitometric values of bands from brains in untreated Atm knock-out mice were arbitrarily set equal to 1 , and other values were normalized to this reference point. added to the microcentrifuge tube containing desalted peptides. Loading solvent was $65 \%$ $\mathrm{ACN} / 2.0 \%$ trifluoroacetic acid (TFA) containing $10 \mathrm{mg} / \mathrm{ml}$ glutamic acid (Sigma-Aldrich). Tubes were vortexed for $60 \mathrm{~min}$, centrifuged for $60 \mathrm{~s}$, and supernatants (non-binding fractions) were saved. Loading solvent was added to the tubes, which were vortexed for $30 \mathrm{~min}$. Tubes were centrifuged again and supernatants (wash fraction 1) were pooled with nonbinding fractions. Wash solvent 1 (65\% ACN/0.5\% TFA) was added to the tubes, vortexed, and centrifuged as in the previous step. The supernatant (second wash fraction) was pooled with the nonbinding and first wash fraction. Wash solvent 2 (50\% ACN/0.1\% TFA) was added to the tubes, which were then vortexed for $30 \mathrm{~min}$. The tubes were centrifuged, and the supernatant (third wash fraction) was pooled with the nonbinding and wash fractions 1 plus 2 . Elution solvent $1\left(50 \% \mathrm{ACN} / 0.3 \mathrm{M} \mathrm{NH}_{4} \mathrm{OH}\right)$ was added to the sample tube and incubated at $45^{\circ} \mathrm{C}$ for $60 \mathrm{~min}$. Tubes were centrifuged and the supernatant (first elution fraction) saved. Elution solvent $2\left(5.0 \% \mathrm{ACN} / 0.3 \mathrm{M} \mathrm{NH}_{4} \mathrm{OH}\right)$ was added to the sample tube and incubated at $45^{\circ} \mathrm{C}$ for $60 \mathrm{~min}$. Tubes with the $\mathrm{TiO}_{2}$ resin were centrifuged, and supernatant (second elution fraction) was pooled with the first elution fraction. Nonbinding plus wash and elution fractions were dried in a speed vac until the volumes were $<50 \mu$ l. Nonbinding plus wash fractions were desalted using the highperformance liquid chromatography (HPLC) instrumentation described recently (Brill et al., 2009). Briefly, $100 \mu \mathrm{l}$ of $95: 5$ solvents A:B was added to the sample, which was injected at 5 $\mu \mathrm{l} / \mathrm{s}$ through a peptide macrotrap (BrukerMichrom). The sample was then desalted with $650 \mu \mathrm{l}$ of $95: 5$ solvents A:B at $5 \mu \mathrm{l} / \mathrm{s}$, eluted with $200 \mu \mathrm{l}$ 50:50 solvents A:B at $6.67 \mu \mathrm{l} / \mathrm{s}$, dried in a speed vac, and resuspended in $100 \mu \mathrm{l}$ of 95:5 solvents A:B. A total of $100 \mu \mathrm{l}$ of $95: 5 /$ solvents $\mathrm{A}: \mathrm{B}$ was added to the $\mathrm{TiO}_{2}$ elution fraction. Each fraction was analyzed by electrospray ionization-(ESI) liquid chromatography-(LC) tandem mass spectrometry (MS/MS), as described below.

ESI-LC-MS/MS. $\mathrm{TiO}_{2}$-based phosphopeptide enrichment was described previously (Ma et al., 2013). A total of $25 \%$ of each $\mathrm{TiO}_{2}$ elution fraction was run twice, and $10 \%$ of each nonbinding plus wash fraction was also run twice. Seven and $14 \mu \mathrm{l}$ of $0.32 \% \mathrm{H}_{3} \mathrm{PO}_{4}$ were added to the remaining elution and nonbinding plus wash fractions, respectively. Each was run again twice as described above. ESI-LCMS/MS used a Paradigm MS2 HPLC, a 0.2 ID $\times 150 \mathrm{~mm}$ Magic C18 column, a captive spray source operated at $1.40 \mathrm{kV}$ (BrukerMichrom), a column heater (Phoenix S \& T) operated at $30^{\circ} \mathrm{C}$ and an LTQ Orbitrap Velos mass spectrometer with electron transfer dissociation (ETD; Thermo Fisher). Instruments were controlled by Xcalibur version 2.6.0 build software (Thermo Fisher) with custom plugins (Bruker-Michrom). The flow rate was $2 \mu \mathrm{l} /$ min with an HPLC gradient of $10-30 \%$ solvent $\mathrm{B}$ (solvent $\mathrm{A}=0.1 \%$ formic acid in water, sol- 
Table 1. Detection of MEF2D phosphopeptides containing the SQ/TQ motif

\begin{tabular}{llllll}
\hline Sample & Protein & Phosphorylated SQ/TQ motif & Instance & $\begin{array}{l}\text { Mass } \\
\text { accuracy (ppm) }\end{array}$ & of proteins \\
\hline $\begin{array}{llll}\text { Untreated } \\
\text { IR }\end{array}$ & MEF2D & NA & 0 & NA & NA \\
\hline
\end{tabular}

NA, Not applicable.

vent $\mathrm{B}=100 \%$ acetonitrile) from 0 to $18 \mathrm{~min}$, $80.0 \%$ B from 18.1 to $24 \mathrm{~min}$, and $10.0 \% \mathrm{~B}$ from 24.1 to $31 \mathrm{~min}$. The decision tree MS/MS method (Swaney et al., 2008) was top 20 datadependent. Precursor ions were scanned in the Orbitrap at a resolution of 60,000, and MS/MS scans were performed in the dual pressure cell linear ion trap. Dynamic exclusion was enabled with a repeat count of 1 , and repeat duration and exclusion duration of $30 \mathrm{~s}$. Via this technique, the mass spectrometer was programmed to isolate given precursor ions, fragment them, scan the masses of the fragments (MS/MS scans), and place the precursors that were fragmented on an exclusion list and thus not subject them to fragmentationMS/MS scans for $30 \mathrm{~s}$, at which time they were often no longer eluting (Ma et al., 2013). The signal threshold to trigger MS/MS scans was 500 counts. Collision-induced dissociation activation used a relative collision energy of 35 and an activation Q of 0.25 for $10 \mathrm{~ms}$. ETD activation was for a maximum of $100 \mathrm{~ms}$ and was automatically controlled by the Xcalibur instrument software.

Searches of MS/MS spectra against protein databases. MS/MS data were searched on the protein database using semitryptic specificity with Sorcerer-SEQUEST on Sorcerer Enterprise hardware/software (SageN Research). Precursor ion mass tolerance was $5 \mathrm{ppm}$, and product ion mass tolerance was 0.5 atomic mass units (amu). Static carbamidomethylation of Cys residues (57.021465 amu), differential oxidation of Met residues (15.99492 amu), and differential phosphorylation of $\mathrm{S}, \mathrm{T}$, and $\mathrm{Y}$ residues $(79.966331 \mathrm{amu})$ were specified. For ETD spectra, the Versasearch script (SageN Research) specified modification of peptide $\mathrm{N}$ termini (b- to c-ions, $17.02655 \mathrm{amu}$ ) and C termini ( $\mathrm{y}$ - to z-radical ions, $-16.018724 \mathrm{amu}$ ) was used to account for the predominance of $\mathrm{c}-$ and z-type, rather than b- and y-type product ions in ETD spectra (Syka et al., 2004). Postsearch filtering was with ProteinProphet (trans-proteomic pipeline, Institute for Systems Biology) at a protein false discovery rate of 0.005-0.009.

Statistical analysis. All data are expressed as mean \pm SEM. Statistical analyses were performed using a Student's $t$ test for single comparisons and an ANOVA for multiple comparisons. Each experiment was performed at least 3 times. $p<0.05$ was considered statistically significant.
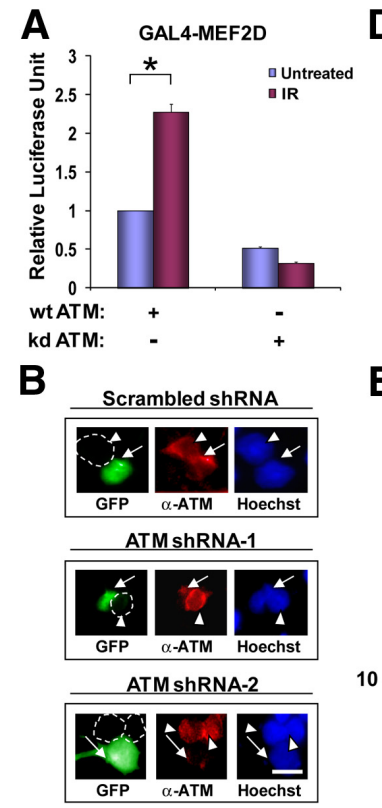

C

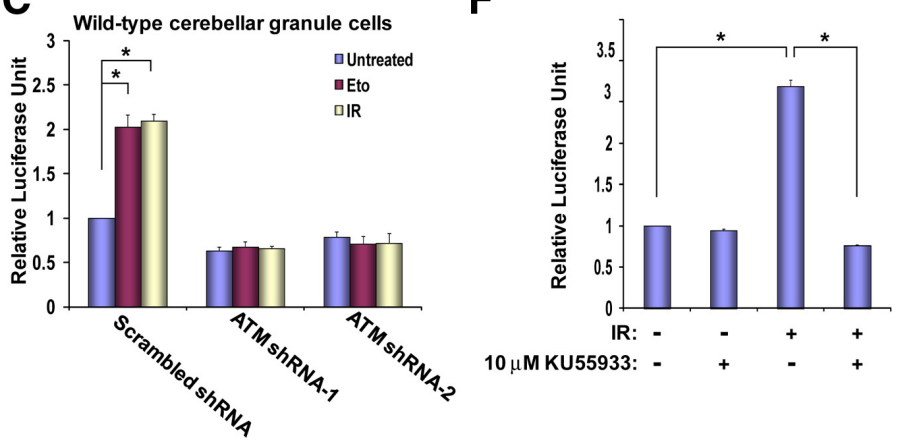

Figure 2. ATM potentiates MEF2 activity in cells after exposure to DNA-damaging agents. A, ATM upregulates MEF2D activity in GAL4-dependent luciferase reporter gene assays. HEK293T cells were cotransfected with two reporter constructs, GAL4-luc and Renilla, plus an expression vector encoding GAL4-MEF2D and either wt- or kd-ATM. Cells were exposed to $10 \mathrm{~Gy}$ IR or control conditions before measuring luciferase activity ( $n=3$ independent experiments). ${ }^{*} p<0.01$ ( $t$ test). Data are mean \pm SEM. $\boldsymbol{B}$, shRNAs directed against ATM decrease ATM expression. Cerebellar granule cells were transfected with shRNA-1, shRNA-2, or scrambled shRNA. Cells were immunostained with anti-ATM antibody, and Hoechst dye 33342 to visualize cell nuclei. Arrows indicate cells transfected with shRNA, and arrowheads and white outlines indicate untransfected cells. Scale bar, $6 \mu \mathrm{m}$. C, ATM shRNAs suppress the potentiation of MEF2 activity after exposure to DNA-damaging agents. Cerebellar granule cells were cotransfected with two reporter constructs, MEF2-luc and Renilla, plus shRNA-1, shRNA-2, or scrambled shRNA. Cells were exposed to IR, etoposide (Eto), or control conditions before measuring luciferase activity ( $n=3$ independent experiments). ${ }^{*} p<0.01$ (ANOVA). D, Cerebellar granule cells from Mef2d $d^{-/-}$mice were cotransfected with two reporter constructs, MEF2-luc and Renilla, and exposed to IR, etoposide (Eto), or control conditions before measuring luciferase activity $(n=3$ independent experiments). $p>$ 0.05 (ANOVA). NS, Not statistically significant. Data are mean \pm SEM. E, KU55933, a small-molecule inhibitor of ATM, prevented activation of ATM kinase activity after exposure to IR. Cerebellar granule cells were immunostained with anti-phospho-SQ/TQ substrate antibody after exposure to IR in the presence or absence of KU55933. Hoechst dye 33342 was used to visualize cell nuclei. Scale bar, $30 \mu \mathrm{m}$. $\boldsymbol{F}$, KU55933 abrogated potentiation of MEF2 activity after exposure to IR. Cerebellar granule cells were cotransfected with two reporter constructs, MEF2-luc and Renilla, and exposed to IR in the presence or absence of KU55933, following which luciferase activity was measured ( $n=3$ independent experiments). ${ }^{*} p<0.01$ (ANOVA). Data are mean \pm SEM.

\section{Results}

ATM phosphorylates MEF2D in vitro and in vivo

Examination of the MEF2D amino acid sequence revealed four putative ATM consensus phosphorylation motifs (SQ/TQ) within the transactivation domain of MEF2D (Fig. 1A). This finding suggested that MEF2D may be phosphorylated directly by ATM. Initially, to determine whether ATM phosphorylates MEF2D in vitro, cell extracts from HEK 293T cells transfected 
A

MMEF2D EPDGEDSLEQSPLLEDKYRRASEELDGLFR hMEF2D EPDGEDSLEQSPLLEDKYRRASEELDGLFR

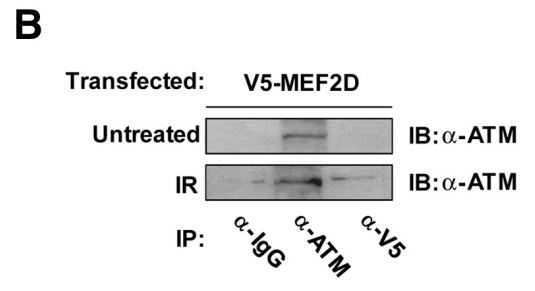

C
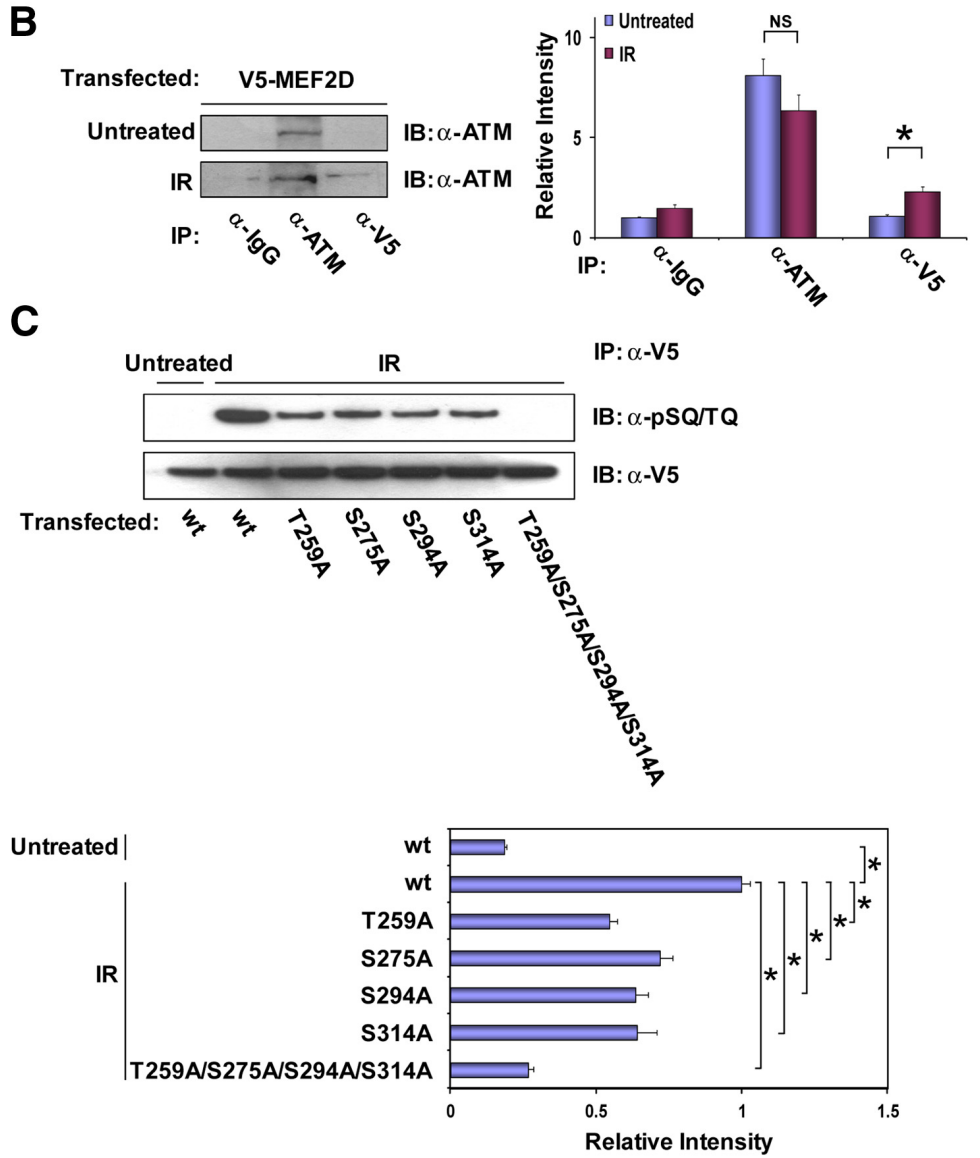

Figure 3. ATM complexes with and phosphorylates MEF2D at specific sites. $A$, Putative ATM-interaction motif in MEF2D. $\mathrm{EE} / \mathrm{DD} / \mathrm{RY}$ doublets are highlighted in red. mMEF2D, Mouse MEF2D; hMEF2D, human MEF2D. $B$, Coimmunoprecipitation of endogenous ATM with MEF2D after exposure to IR. Left, HEK293T cells were transfected with an expression vector encoding V5-tagged wt-MEF2D. After exposure to $10 \mathrm{~Gy}$ IR or control conditions, cell extracts were immunoprecipitated (IP) with anti-ATM, anti-V5, or control anti-IgG antibody. Immunoblots (IB) were probed with anti-ATM antibody. Right, Densitometric analysis of immunoblots was performed, and the relative densitometric values are presented as mean $\pm \mathrm{SEM} ; n=3$ independent experiments. ${ }^{*} p<0.01$ (ANOVA). NS, Not statistically significant. C, Identification of ATM-phosphorylatable sites in MEF2D. HEK293T cells were transfected with plasmids expressing wt or MEF2D mutants (T259A, S275A, S294A, S314A, or T259A/S275A/S294A/S314A), each tagged with V5. Transfected cells were then exposed to $10 \mathrm{~Gy} I R$ and immunoprecipitated with anti-V5 antibody. Top, ATM-phosphorylated MEF2D proteins were detected with anti-phospho-SQ/TQ substrate antibody. Total MEF2D protein expression was detected with anti-V5 antibody. Bottom, Densitometric analysis of immunoblots was performed, and the relative densitometric values are presented as mean \pm SEM; $n=3$ independent experiments. ${ }^{*} p<0.01$ (ANOVA). The densitometric values of treated cells that were transfected with wt-MEF2D were arbitrarily set equal to 1 , and other values were normalized to this reference point.

with cDNAs encoding Flag-tagged wt (catalytically active) or kd (representing a dominant negative) ATM were immunoprecipitated using anti-Flag antibody. We then incubated the immunoprecipitants with recombinant His-tagged MEF2D fusion proteins or GST-p53 (an ATM substrate) and $\left[\gamma^{-32} \mathrm{P}\right]$ ATP. We detected ${ }^{32} \mathrm{P}$-labeled His-tagged MEF2D and GST-p53 in the presence of wt-ATM but not kd-ATM (Fig. 1B). These results show that ATM can phosphorylate MEF2D in vitro.

ATM plays a pivotal role in the cellular response to DNA DSBs (Khanna et al., 2001; Shiloh, 2003). Hence, we asked whether ATM phosphorylates MEF2D in the cerebellum in response to DNA damage. For this purpose, we used primary cerebellar granule cells, a cell type known to be significantly affected in AT. These cells were exposed to DNA-damaging agents, IR, or the topoisomerase II inhibitor etoposide to induce DSBs in DNA. Cell extracts were immunoprecipitated with anti-MEF2D or a control anti-IgG antibody.
ATM-phosphorylated MEF2D proteins were detected by immunoblotting with an anti-phospho-SQ/TQ substrate antibody that can detect phosphorylated ATM substrates. After exposure to irradiation or etoposide, the level of ATMphosphorylated MEF2D increased (Fig. $1 C)$. To confirm phosphorylation, we incubated immunoprecipitants with alkaline phosphatase, which abrogated the effect on MEF2D (Fig. 1C). Cerebellar granule cells were also exposed to two stressors that do not induce DSBs, UV light and staurosporine (a kinase inhibitor). Neither caused an increase in the level of ATM-phosphorylated MEF2D protein (Fig. 1D). These results suggest that DNA-damaging agents that specifically induce DSBs trigger phosphorylation of MEF2D.

To verify that the phosphopeptide containing the SQ/TQ motif in the antiMEF2D immunoprecipitates was from MEF2D and not an associated protein, we performed titanium dioxide $\left(\mathrm{TiO}_{2}\right)$ based phosphopeptide enrichment-LCMS/MS. For this purpose, we exposed cells to IR (10 Gy) or control conditions and subsequently immunoprecipitated cell lysates using anti-MEF2D antibodies that had been covalently attached to beads. We then eluted proteins from the beads and analyzed them using Western blots and $\mathrm{TiO}_{2}$-LC-MS/MS. Consistent with our prior results, in samples from the irradiated cells but not the untreated cells, Western blots probed with an antibody specific for phospho-SQ/TQ revealed a single band of the expected molecular weight of MEF2D. In $\mathrm{TiO}_{2}$-LC-MS/MS analysis, we identified a phosphopeptide from MEF2D that contained the SQ/TQ motif (PAKSPPPPp[THST]QLGAPSR, representing amino acids 248-266) in the irradiated samples, but not in the untreated controls (Table 1). In contrast, we did not detect other proteins that contained phosphorylated SQ/TQ motif (Table 1).

To gather further evidence that ATM is the kinase mediating MEF2D phosphorylation after DNA damage, we prepared cerebellar granule cells from Atm wt and knock-out mice and exposed the cells to etoposide or control. We detected ATM-phosphorylated MEF2D proteins in ATM wt cells but not in ATM-deficient cells after etoposide exposure (Fig. 1E). We also performed densitometric analysis of the immunoblots and observed an $\sim 2$-fold increase of ATMphosphorylated MEF2D proteins in ATM wt cells after etoposide exposure compared with control conditions (Fig. 1E). These results are consistent with the notion that ATM catalyzes phosphorylation of MEF2D in response to DNA damage. To demonstrate MEF2 phosphorylation by ATM in vivo, we exposed the heads of adult wt and Atm knock-out mice to 10 Gy IR or control (unexposed) conditions. We found phosphorylated MEF2D protein in the brains of wt but not Atm knock-out mice after irradiation (Fig. $1 F$ ), consistent with the notion 


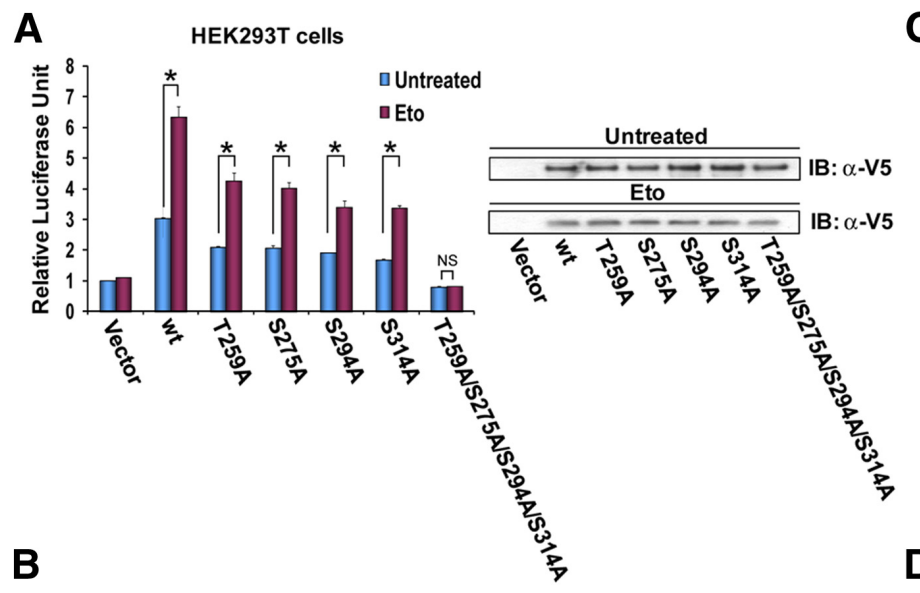

\section{HEK293T cells}
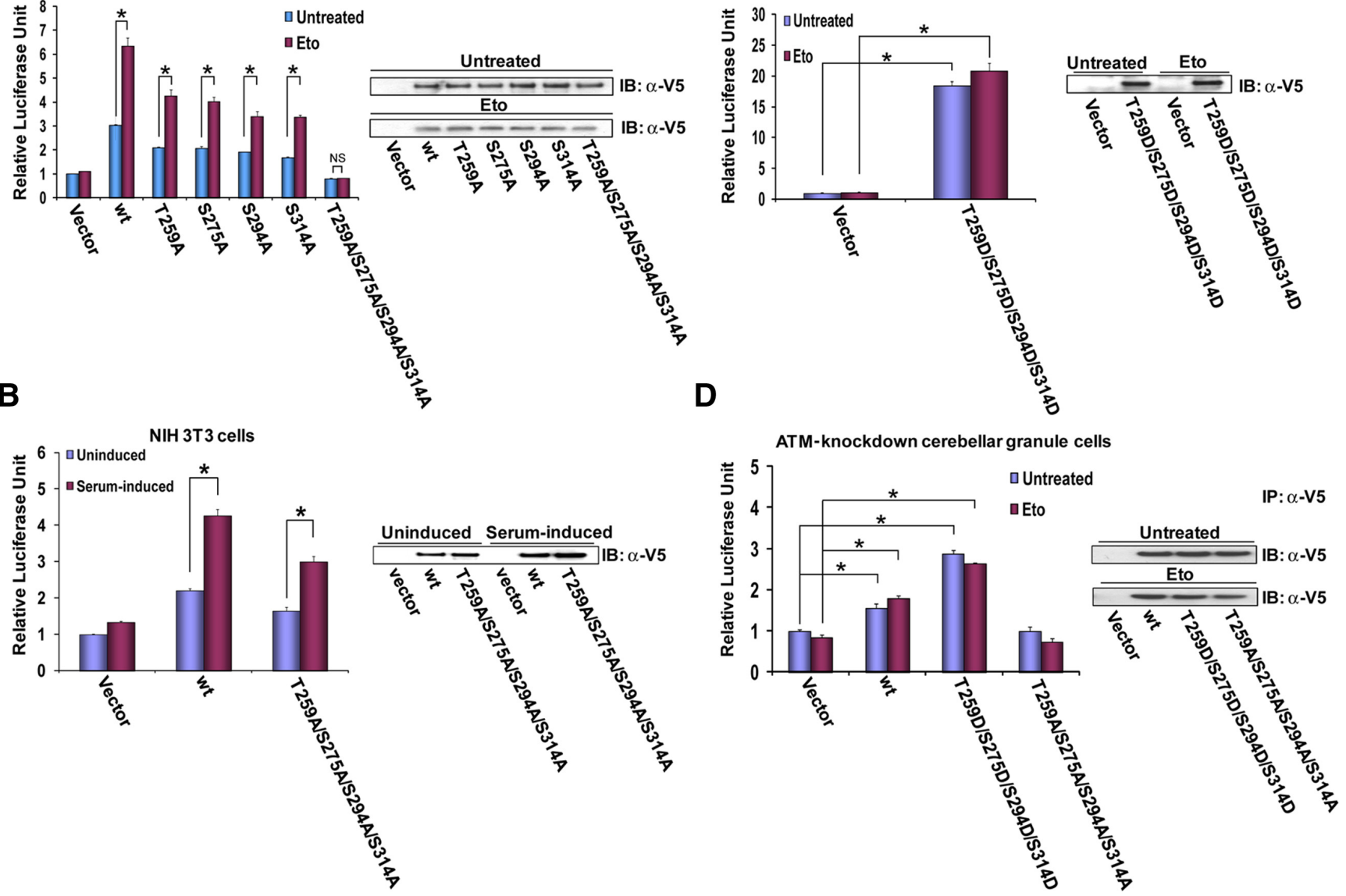

Figure 4. Effect of phosphomimetic MEF2D and nonphosphorylatable MEF2D mutations on MEF2 activity. A, Each of the four ATM-phosphorylatable sites in MEF2D contributes to full activation after DNA damage. HEK293T cells were cotransfected with the following expression plasmids: two reporter constructs, MEF2-luc and Renilla, plus wt MEF2D, nonphosphorylatable MEF2D mutant (T259A/S275A/S294A/S314A), MEF2D mutant containing three putative ATM-phosphorylatable sites and a single alanine substitution (T259A, S275A, S294A, or S314A), or pCDNA3 vector control. One day after transfection, cells were exposed to etoposide (Eto) or control (untreated) conditions before measuring luciferase activity ( $n=3$ independent experiments). ${ }^{*} p<0.01$ (ANOVA). NS, Not statistically significant. Data are mean \pm SEM. $B$, Effect of nonphosphorylatable MEF2D mutations on MEF2 activity after serum induction. NIH 3 T3 cells were cotransfected with two reporter constructs, MEF2-luc and Renilla, plus wt-MEF2D, nonphosphorylatable MEF2D mutant (T259A/S275A/S294A/S314A), or pcDNA3 vector control. The transfected cells were serum starved for $30 \mathrm{~h}$ and then treated with serum for $2 \mathrm{~h}$ before preparation of cell lysates for luciferase assays $\left(n=3\right.$ independent experiments). ${ }^{*} p<0.01$ (ANOVA). Data are mean \pm SEM. $C$, Effect of phosphomimetic MEF2D mutations on MEF2 activity in HEK293T cells. Cells were cotransfected with two reporter constructs, MEF2-luc and Renilla, plus wt-MEF2D, nonphosphorylatable MEF2D mutant (T259A/ S275A/S294A/S314A), phosphomimetic MEF2D mutant (T259D/S275D/S294D/S314D), or pcDNA3 vector control. One day after transfection, transfected cells were exposed to etoposide or control (untreated) condition s before measuring luciferase activity. Basal luciferase activity of the untreated vector control was arbitrarily set to 1 , and all other values were normalized to this reference point ( $n=3$ independent experiments). ${ }^{*} p<0.01$ (ANOVA). Data are mean \pm SEM. $\boldsymbol{D}$, Effect of phosphomimetic MEF2D mutations on MEF2 activity after ATM knockdown in cerebellar granule cells. Cells were cotransfected with shRNA-1 and two reporter constructs, MEF2-luc and Renilla, plus wt-MEF2D, nonphosphorylatable MEF2D mutant (T259A/S275A/S294A/S314A), phosphomimetic MEF2D mutant (T259D/S275D/S294D/S314D), or pCDNA3 vector control. Three days after transfection, cells were exposed to etoposide or control (untreated) conditions before measuring luciferase activity. Basal luciferase activity of the untreated vector control was arbitrarily set to 1 , and other values were normalized to this reference point ( $n=3$ independent experiments). ${ }^{*} p<0.01$ (ANOVA). Data are mean \pm SEM. Protein expression levels of wt and MEF2D mutant constructs are shown to the right of each panel.

that ATM induces phosphorylation of MEF2D in response to DNA damage in vivo.

\section{ATM potentiates MEF2 activity after cell exposure to agents causing DNA damage}

MEF2 activity can be modulated by several different phosphorylation events (Li et al., 2001; Flavell and Greenberg, 2008). In this study, we therefore investigated the effect of ATM-mediated phosphorylation on MEF2D transcriptional activity. We used GAL4dependent luciferase reporter gene assays to measure MEF2 activity in HEK293T cells. As a control, transfection with GAL4-Luc alone did not produce any signal (data not shown). In these experiments, cells were cotransfected with two reporter constructs, GAL4-luc and Renilla, plus an expression vector encoding the DNA binding domain of the transcription factor protein GAL4 fused to the transac- tivation domain of MEF2D, and either wt- or kd-ATM. The transfected cells were then exposed to IR or control conditions before luciferase activity was measured. After irradiation, overexpression of wt-ATM significantly upregulated MEF2D activity, whereas kd-ATM suppressed MEF2D activation (Fig. 2A).

Next, we used a reporter gene system containing a MEF2dependent luciferase gene (MEF2-luc) to determine how ATM regulates endogenous MEF2 activity in cerebellar granule cells. First, we knocked down ATM expression with a U6 promoter-driven short-hairpin RNA (shRNA). Cerebellar granule cells were transfected with two different shRNAs directed against ATM (designated shRNA-1 and shRNA-2) or a scrambled shRNA, and then immunostained with anti-ATM antibody to detect ATM expression. We found that shRNA-1 and shRNA-2 efficiently inhibited ATM expression, but the nontarget 
A

Scrambled shRNA

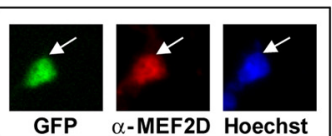

MEF2D shRNA-436

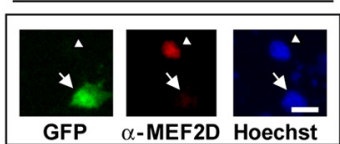

B

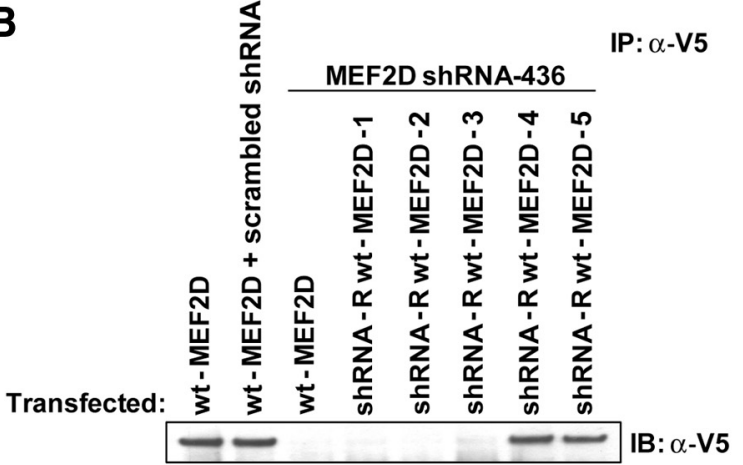

\section{C}

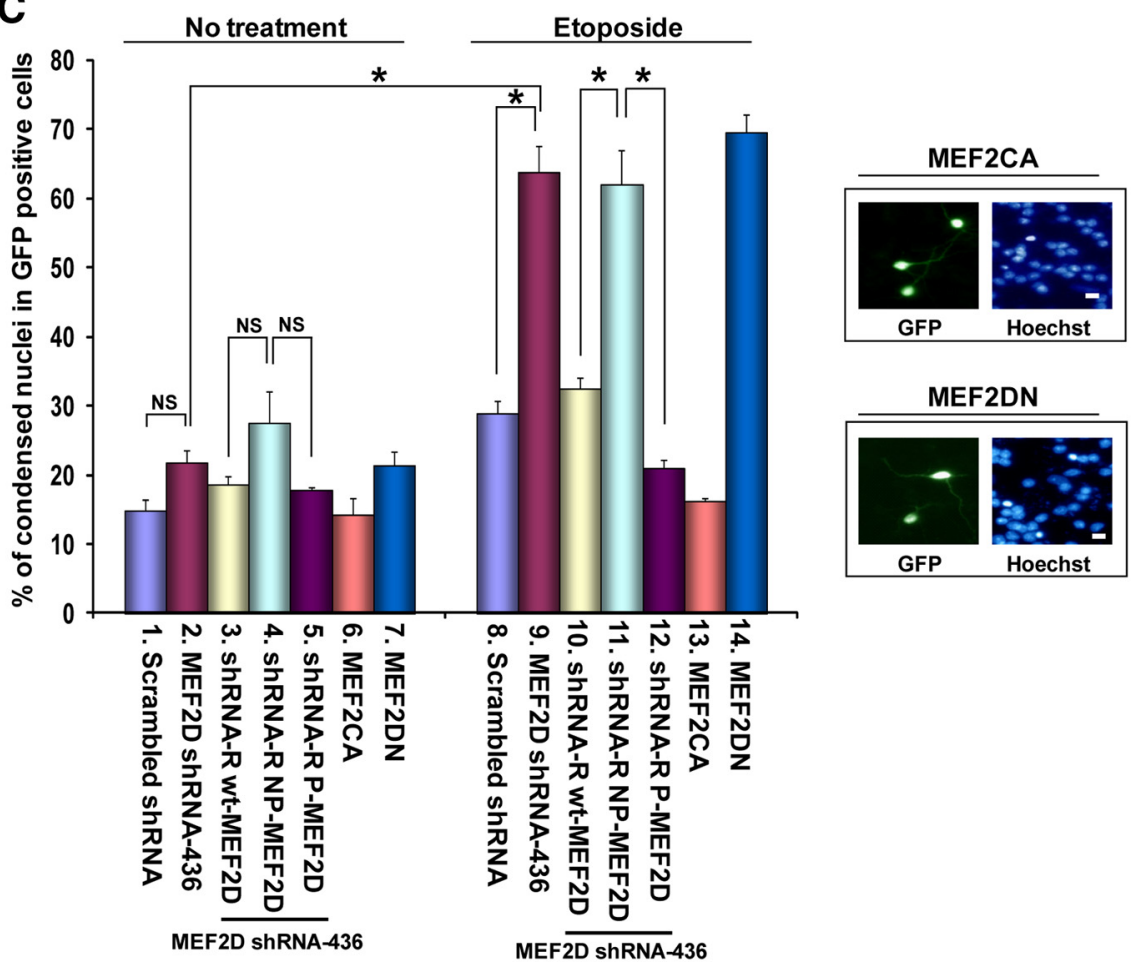

Figure 5. Effect of shRNA on endogenous MEF2D expression in cerebellar granule cells and construction of shRNAresistant forms of MEF2D CDNAs. A, Cerebellar granule cells from rat were transfected with shRNA-MEF2D-436 or scrambled shRNA. Two days after transfection, cells were immunostained with anti-MEF2D antibody to detect MEF2D and Hoechst dye 33342 to visualize cell nuclei. Arrows indicate cells transfected with shRNA, and arrowheads indicate untransfected cells. Scale bar, $6 \mu \mathrm{m}$. B, MEF2D CDNAs bearing silent mutations in the region targeted by shRNA-MEF2D-436 manifest resistance to RNAi. HEK293T cells were transfected with plasmids expressing shRNA-MEF2D-436 plus an shRNA-resistant form of wt-MEF2D (designated wt-MEF2D-1-5). Additionally, cells were transfected with wt-MEF2D plus scrambled shRNA or shRNA-MEF2D-436 as a control. Two days after transfection, cell extracts were immunoprecipitated (IP) with anti-V5 antibody. MEF2D expression was then detected by immunoblotting (IB) with anti-V5 antibody. C, DNA damage induces apoptosis after MEF2D knockdown in rat cerebellar granule cells in vitro. Cerebellar granule cells from rat expressing MEF2D shRNA were more susceptible to etoposide-induced cell death. Cells were cotransfected with the indicated expression plasmids, and after $3 \mathrm{~d}$ exposed to etoposide (Eto, $10 \mu \mathrm{m}$ for $8 \mathrm{~h}$ ) or control conditions (untreated). The number of GFP-transfected cells was counted for each condition. Hoechst dye 33342 was used to identify condensed nuclei, indicative of apoptotic cell death ( $n>300$ cells counted in three independent experiments). ${ }^{*} p<0.05$ (ANOVA). NS, Not statistically significant. shRNA-R is the shRNA-resistant form. Representative cells expressing MEF2CA or MEF2DN (no treatment) are illustrated. Data are mean \pm SEM. NP, Nonphosphorylatable; P, phosphomimetic. scrambled shRNA did not (Fig. 2B). Second, we cotransfected cerebellar granule cells with two reporter constructs, MEF2luc and Renilla, plus shRNA-1, shRNA-2, or the scrambled shRNA as a control. We found that exposure of cells to IR or etoposide activated endogenous MEF2 activity (Fig. 2C). Unlike the scrambled shRNA, shRNA-1 and shRNA-2 against ATM inhibited MEF2 activation under these conditions (Fig. $2 C)$. We also found that there was no significant change in endogenous MEF2 activity in MEF2D-null cerebellar granule cells after exposure to etoposide or IR (Fig. 2D). These results suggest that MEF2D is required for MEF2 reporter gene activation in response to DNA damage.

To further confirm that ATM activates endogenous MEF2 activity after DNA damage, we used a cell-permeable smallmolecule inhibitor of ATM, KU55933, to inhibit ATM kinase activity (Hickson et al., 2004). Cerebellar granule cells were immunostained with anti-phospho-SQ/TQ substrate antibody to detect activation of ATM kinase after exposure to IR in the presence or absence of KU55933. We found that KU55933 abrogated ATM kinase activity under these conditions (Fig. $2 E)$. Next, we transfected cerebellar granule cells with two reporter constructs, MEF2-luc and Renilla, and exposed the cells to IR in the presence or absence of KU55933. We found that KU55933 abrogated irradiation-induced activation of endogenous MEF2 activity (Fig. $2 F$ ).

\section{ATM and MEF2D form a complex after DNA damage}

If a protein contains an ATM-interaction motif, represented by EE/DD/RY doublets, ATM is likely to associate with and phosphorylate the protein (Falck et al., 2005). Examination of both mouse and human MEF2D amino acid sequences revealed such an ATM-interaction motif (Fig. 3A). To test whether ATM forms a complex with MEF2D, we transiently transfected HEK293T cells with an expression vector encoding V5-tagged wtMEF2D. After exposure to IR, cell extracts were immunoprecipitated with control antibody (anti-IgG), anti-ATM, or anti-V5 antibody, and then immunoblotted with anti-ATM antibody. The anti-V5 antibody coimmunoprecipitated MEF2D and endogenous ATM in irradiated cells, but not in unexposed cells (Fig. 3B). These results are consistent with the notion that ATM and MEF2D may form a complex in mammalian cell lines in response to DNA damage. 
ATM phosphorylates MEF2D on amino acids Thr259, Ser275, Ser294, and Ser314

From the amino acid sequence of MEF2D, we identified four putative ATM consensus phosphorylation motifs (representing the SQ/TQ motifs) within the MEF2D transactivation domain (Fig. 1A). Hydrophobic and negatively charged amino acids adjacent to the amino terminal of S/T are positive determinants, whereas positively charged amino acids are negative determinants for substrate phosphorylation (Kim et al., 1999; O'Neil et al., 2000). To determine which of the four serine/threonine residues (Thr259, Ser275, Ser294, and Ser314) in MEF2D is phosphorylated by ATM, we mutated each to alanine (A), either singly or in combination. We transfected HEK293T cells with expression plasmids encoding either V5-tagged wt-MEF2D or each MEF2D mutant (T259A, S275A, S294A, S314A or T259A/S275A/S294A/ S314A). The transfected cells were exposed to IR or control (untreated) conditions, and cell extracts immunoprecipitated with anti-V5 antibody. We detected ATM-phosphorylated MEF2D proteins by immunoblotting with anti-phospho-SQ/TQ substrate antibody. Mutation of each putative site partially reduced ATM-mediated phosphorylation of MEF2D, whereas mutation of all four sites abrogated ATM phosphorylation completely and thus represents a nonphosphorylatable MEF2D mutant (Fig. $3 C$ ). These results are consistent with the notion that ATM phosphorylates MEF2D at four sites (Thr259, Ser275, Ser294, and Ser314).

Next, we investigated which of the ATM-phosphorylatable sites in MEF2D is essential for MEF2 activity after DNA damage. We first transfected HEK293T cells with two reporter constructs, MEF2-luc and Renilla, and an expression vector encoding wtMEF2D, the nonphosphorylatable MEF2D mutant, or each MEF2D single phosphorylation site-mutant. We then exposed the transfected cells to etoposide to induce DSBs and measured luciferase activity. After etoposide exposure, MEF2 activity substantially increased in cells expressing wt-MEF2D, but not in cells expressing nonphosphorylatable MEF2D mutant (Fig. 4A). These findings suggest that the nonphosphorylatable MEF2D mutant cannot be activated by DNA damage. The nonphosphorylatable MEF2D mutant was nevertheless functional, as demonstrated by induction of MEF2 activity with other stimuli (Fig. 4B). Although we observed some increase in MEF2 activity after etoposide exposure with expression of each MEF2D single phosphorylation site-mutant, the increase was less than with wt-MEF2D (Fig. $4 A$ ). These results suggest that each ATM-phosphorylatable site contributes to MEF2D activation in response to DNA damage.

We also performed the converse series of experiments, studying the effect of phosphomimetic MEF2D mutations on MEF2 reporter activity in mammalian cell lines. We constructed a phosphomimetic MEF2D mutant by converting all four ATMphosphorylatable sites on MEF2D to aspartic acid residues (T259D/S275D/S294D/S314D). HEK293T cells were then cotransfected with two reporter constructs, consisting of MEF2-luc and Renilla, plus either phosphomimetic MEF2D mutant or vector control. The transfected cells were then exposed to etoposide or control conditions before measuring luciferase activity. Cells expressing the phosphomimetic MEF2D mutant displayed elevated MEF2 reporter activity even in the absence of etoposide exposure (Fig. 4C).

Next, we examined the effect of phosphomimetic MEF2D mutations on MEF2 activity after ATM knockdown in cerebellar granule cells. Cells were cotransfected with an shRNA directed against ATM (shRNA-1) and two reporter constructs, MEF2-luc and Renilla, plus wt-MEF2D, nonphosphorylatable MEF2D mu-
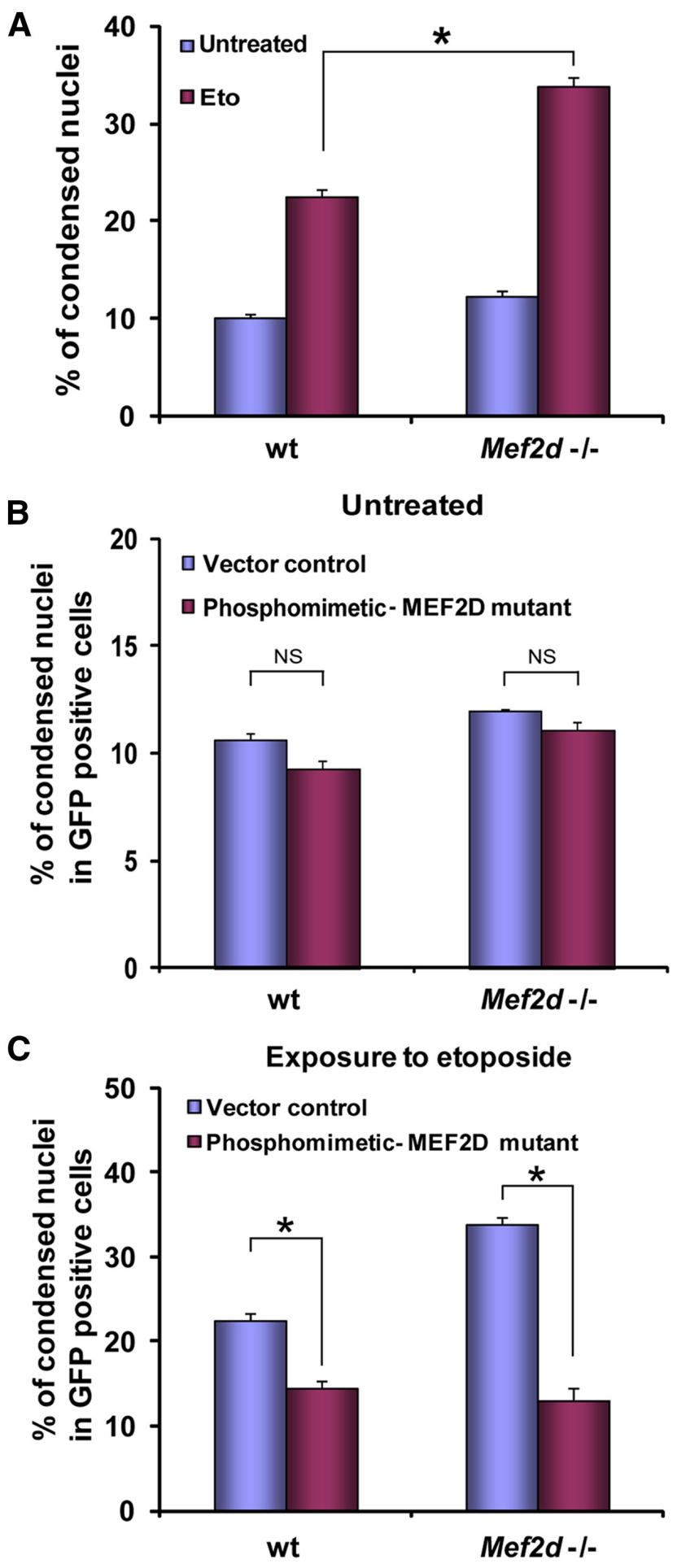

Figure 6. Mef2 $d^{-1-}$ cerebellar granule cells manifest increased susceptibility to DNA damage. $A$, Cultured cerebellar granule cells from Mef2d wt and knock-out mice were exposed to etoposide (Eto) or control conditions. Hoechst dye 33342 was used to identify condensed nuclei, indicative of apoptotic cell death ( $n>200$ cells counted in three independent experiments). ${ }^{*} p<0.05$ (ANOVA). B, Cultured cerebellar granule cells from Mef2d wt and knock-out mice were transfected with a GFP expression construct, plus either phosphomimetic MEF2D or vector control. The number of GFP-transfected cells was counted for each condition. Hoechst dye 33342 was used to identify condensed nuclei $(n>200$ cells counted in three independent experiments). $p>0.05$ ( $t$ test). NS, Not statistically significant. C, Cultured cerebellar granule cells from Mef2d wt and knock-out mice were transfected with a GFP expression construct, plus either phosphomimetic MEF2D or vector control, and exposed to Eto. The number of GFPtransfected cells was counted for each condition. Hoechst dye 33342 was used to identify condensed nuclei ( $n>200$ cells counted in three independent experiments). ${ }^{*} p<0.05$ (ANOVA). 
A

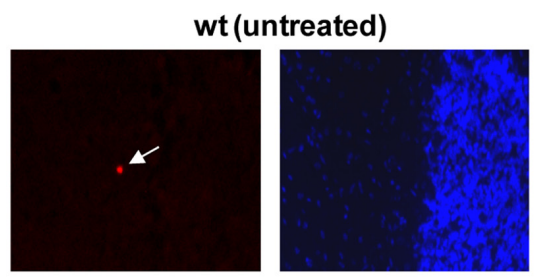

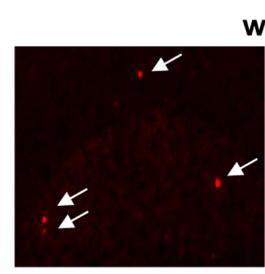

TUNEL wt (IR)

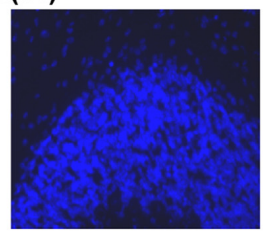

Hoechst

B

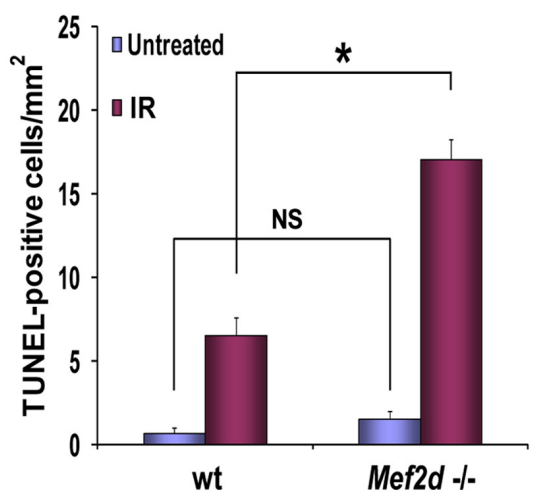

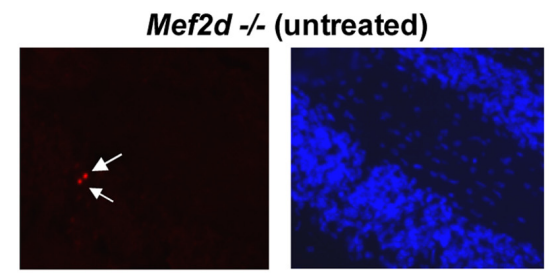

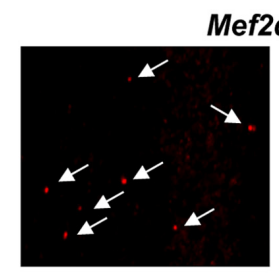

TUNEL

C

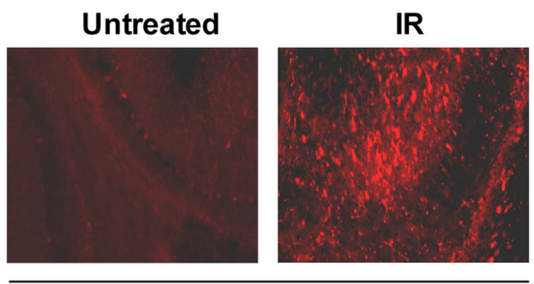

wt

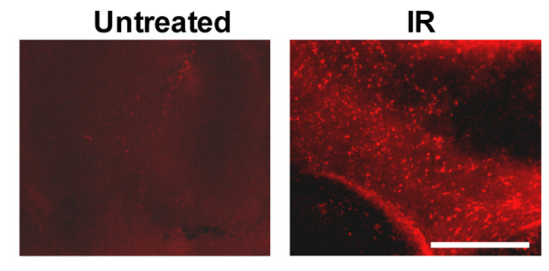

Mef2d -/-

Figure 7. Mef2d $d^{-1-}$ mice are more susceptible to DNA damage induced by IR. $A$, Brains of wt and Mef2d knock-out mice $\left(\right.$ Mef2 $d^{-I-}$ ) at postnatal day (P) 18 were exposed to $10 \mathrm{~Gy}$ IR or control conditions (untreated), and cerebellar brain slices were subsequently labeled with TUNEL. Arrows indicate TUNEL-positive cells. Scale bar, $50 \mu \mathrm{m}$. B, Quantification of TUNEL-positive cells in Mef2 $d^{-1-}$ brains shows increased cell death after IR than in wt brains ( $n>100$ cells counted in three independent experiments). ${ }^{*} p<0.05$ (ANOVA). NS, Not statistically significant. Data are mean \pm SEM. C, DNA damage increases mitochondrial superoxide formation in wt and $M e f 2^{-1-}$ cerebellar brain slices. Increased fluorescence of the mitochondrial superoxide specific dye, MitoSOX, in brain slices in response to $10 \mathrm{~Gy}$ IR. Slices visualized under epifluorescence microscopy. Scale bar, $400 \mu \mathrm{m}$.

tant (T259A/S275A/S294A/S314A), phosphomimetic MEF2D mutant (T259D/S275D/S294D/S314D), or pcDNA3 vector control. The transfected cells were exposed to etoposide or control (untreated) conditions before measuring luciferase activity. We found that MEF2 activity was stimulated in cells expressing the phosphomimetic MEF2D mutant in which ATM was knocked down, regardless of etoposide exposure. In contrast, the MEF2 reporter was not activated in cells expressing the nonphosphorylatable MEF2D mutant (Fig. 4D). Together, these results are consistent with the notion that phosphomimetic MEF2D mutant can simulate DNA damage-induced activation of MEF2.

\section{ATM-dependent phosphorylation/activation of MEF2D} contributes to neuronal survival in response to DNA damage Activation of MEF2 is critical for neuronal survival in the brain (Ikeshima et al., 1995; Lyons et al., 1995; Okamoto et al., 2000, 2002; Gaudilliere et al., 2002; Shalizi et al., 2003, 2006; Flavell and Greenberg, 2008; Li et al., 2008, 2012). We examined how DNA damage affects rat cerebellar granule cell viability after knockdown of endogenous MEF2D expression with shRNAs (shRNA-
MEF2D) or substitution of endogenous MEF2D with one of three shRNA-resistant forms of MEF2D (wt-MEF2D, nonphosphorylatable MEF2D mutant, or phosphomimetic MEF2D mutant).

We constructed an shRNA specific to MEF2D (designated shRNA-MEF2D436) and examined its ability to knock down endogenous MEF2D in rat cerebellar granule cells. Immunostaining with an anti-MEF2D antibody confirmed that shRNA-MEF2D-436, but not scrambled shRNA, efficiently silenced endogenous MEF2D expression in cerebellar granule cells (Fig. 5A). Next, we introduced one of five different silent mutations at the shRNA-MEF2D-436 target site in an expression plasmid encoding wt-MEF2D, nonophosphorylatable-MEF2D mutant, or phosphomimetic MEF2D mutant. We then examined whether these silent mutations could provide resistance to shRNAmediated suppression of MEF2D in HEK293T cells. We found that only mutants 4 and 5 displayed resistance to shRNA-MEF2D-436 (Fig. 5B).

With these tools in hand, we transfected rat cerebellar granule cells with shRNA-MEF2D-436, control scrambled shRNA, or shRNA-MEF2D-436 plus one of the three shRNA-resistant forms of MEF2D (i.e., mutant 4 embodied in wtMEF2D, nonphosphorylatable MEF2D mutant, or phosphomimetic MEF2D mutant). We quantified apoptotic cell death after the transfected cells were exposed to etoposide or control conditions and found that cerebellar granule cells expressing shRNA-MEF2D-436 were more susceptible to etoposide-induced cell death than those expressing control scrambled shRNA (Fig. 5C, columns 2 vs 9). Interestingly, substitution of endogenous MEF2D with an shRNA-resistant form of phosphomimetic MEF2D mutant protected from cell death after etoposide exposure to an even greater degree than the shRNA-resistant form of wt-MEF2D (Fig. $5 C$, columns 10 vs 12). In contrast, substitution of endogenous MEF2D with an shRNA-resistant form of nonphosphorylatable MEF2D mutant did not afford neuroprotection (Fig. 5C, columns 10 vs 11 and columns 11 vs 12). A dominant-negative MEF2 (MEF2DN), previously shown to inhibit MEF2 activity and enhance cell death after NMDA insult, also increased cell death after etoposide exposure, whereas a constitutively active form of MEF2 (MEF2CA) prevented cell death (Fig. 5C, columns 13 and 14) (Okamoto et al., 2000). Together, these results are consistent with the notion that knockdown of endogenous MEF2D increases sensitivity to etoposide-induced neuronal cell death in the cerebellum. Rescue of cerebellar neurons by overexpression of an shRNA-resistant form of phosphomimetic MEF2D mutant (but not an shRNA-resistant form of nonphosphorylatable MEF2D mutant) suggests that ATM-induced phosphorylation/ activation of MEF2D is essential for neuronal survival after DNA damage. 
Further along these lines, we examined whether cerebellar granule cells from Mef $2 d$ knock-out (Mef2 $\left.d^{-1-}\right)$ mice would manifest increased susceptibility to DNA damage compared with wt. We quantified apoptotic cell death after the cells were exposed to etoposide or control conditions. Consistent with our MEF2D knockdown experiments, we found that Mef $2 d^{-1-}$ cerebellar granule cells displayed an increase in sensitivity to etoposide-induced neuronal cell death compared with wt (Fig. 6A). Whereas expression of phosphomimetic MEF2D mutant in either wt or Mef $2 d^{-1-}$ cerebellar granule cells did not increase baseline survival (Fig. 6B), expression of phosphomimetic MEF2D mutant protected both wt and $M e f 2 d^{-1-}$ cerebellar granule cells from death after etoposide exposure (Fig. 6C).

To determine whether loss of MEF2D in vivo affects neuronal survival, we exposed the brains of wt mice and Mef2dknock-out mice (Mef2 $d^{-/-}$) at P18 to 10 Gy irradiation. We then stained cerebellar brain sections from these mice for apoptotic cells. At P18, we found a significant increase in TUNEL-positive cells per unit area of cerebellar folia in $\mathrm{Mef} 2 d^{-1-}$ mice in response to irradiation compared with wt controls (Fig. 7A,B). We also stained brain sections with MitoSOX, a fluorescent indicator of mitochondrial superoxide (Liu et al., 2007; Robinson et al., 2008). We observed a significant increase in fluorescence intensity in wt and $M e f 2 d^{-1-}$ cerebellar brain slices after irradiation compared with controls, suggesting an increase in mitochondrial superoxide formation (Fig. 7C), which is known to be associated with DNA damage and to trigger ATM activation (Guo et al., 2010). Together, these results suggest that MEF2D is a target of ATM phoshporylation that protects cerebellar neurons from DNA damage both in vitro and in vivo.

Additionally, to identify a potential prosurvival molecular target of MEF2D that protects against cell death after DNA damage, we prepared mRNAs and protein lysates from cerebella of P18 wt and Mef $2 d^{-1-}$ mice after irradiation (10 Gy). We had previously identified MEF2 binding sites in the regulatory region of the neuroprotective $B c l-x L$ gene and showed that MEF2 binds to its cognate sites on the $B c l-x L$ promoter region to regulate transcriptional activity (Li et al., 2008; Okamoto et al., unpublished observations). In the present study, using qRT-PCR and immunoblot analyses, we found that the levels of $\mathrm{Bcl}-\mathrm{xL}$ mRNA and protein were
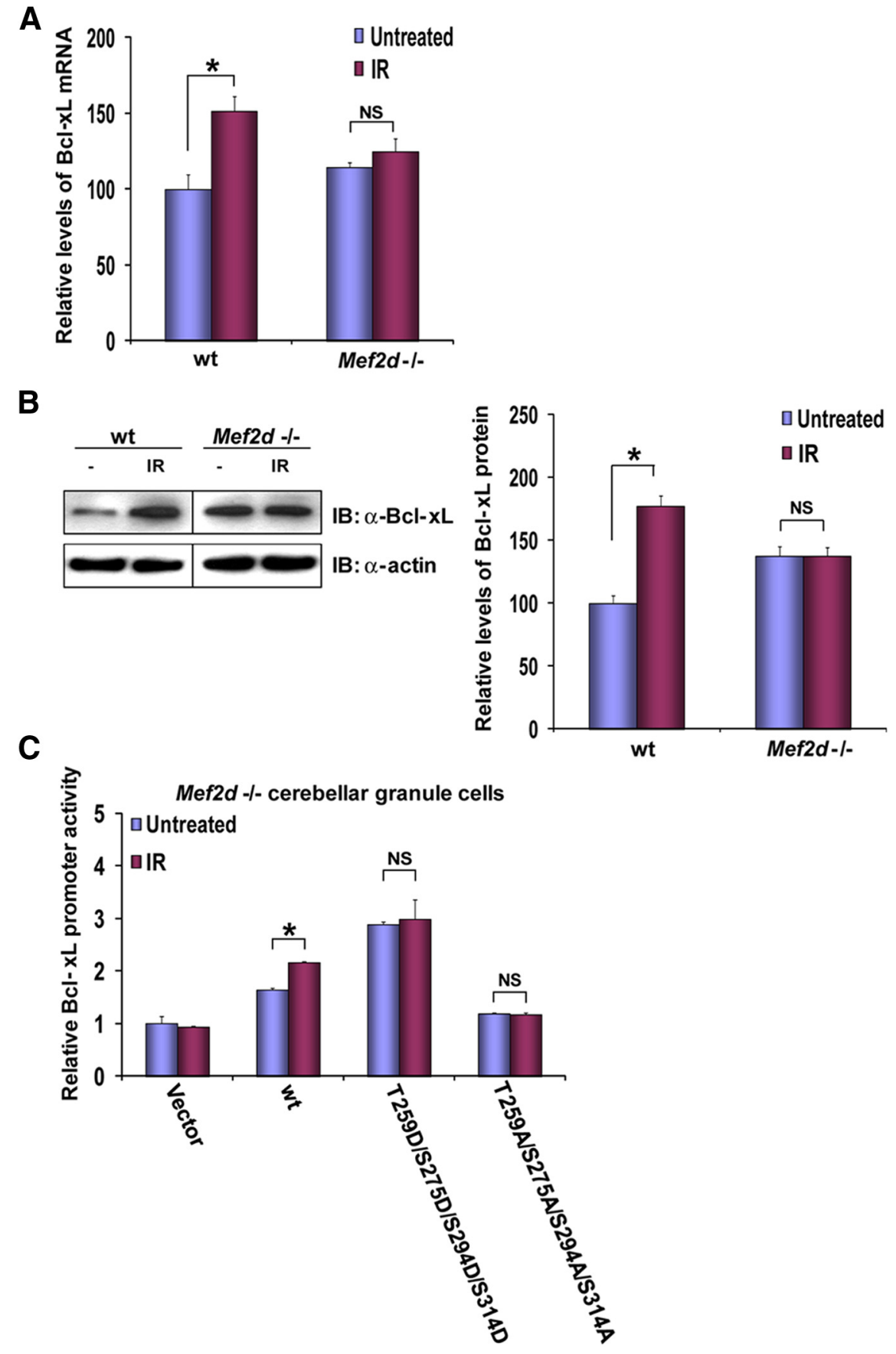

Figure 8. MEF2D upregulates BCl-xL expression after exposure to IR. A, qRT-PCR analysis of BCl-xL mRNA expression level. Brains of wt and Mef2d knock-out mice (Mef2d ${ }^{-I-}$ ) were exposed to 10 Gy IR or control conditions (untreated), and cerebellar brain mRNAs subsequently prepared for qRT-PCR. Expression of untreated wt samples was arbitrarily set to a value of 100 , and other values normalized to this reference point with GAPDH as an internal control $(n=3$ independent experiments). $p<0.05$ (ANOVA). NS, Not statistically significant. Data are mean \pm SEM. $\boldsymbol{B}$, Western blot analysis of cerebellar brain lysates from wt and Mef2 $d^{-1-}$ mice after $10 \mathrm{~Gy}$ IR with $\mathrm{BCl}-\mathrm{xL}$ and actin protein expression levels quantified. Expression of untreated wt samples was arbitrarily set to a value of 100 , and other values normalized to this reference point with actin as the control ( $n=3$ independent experiments). ${ }^{*} p<0.01$ (ANOVA). NS, Not statistically significant. Data are mean \pm SEM. C, Effect of phosphomimetic MEF2D mutations on BCl-xL promoter activity in Mef2d $d^{-l-}$ cerebellar granule cells. Cells were cotransfected with two reporter constructs, BCl-xL-luc and Renilla, plus wt-MEF2D, nonphosphorylatable MEF2D mutant (T259A/S275A/S294A/S314A), phosphomimetic MEF2D mutant (T259D/S275D/ S294D/S314D), or pcDNA3 vector control. The transfected cells were exposed to $10 \mathrm{~Gy} \mathrm{IR} \mathrm{or} \mathrm{control} \mathrm{(unexposed)} \mathrm{conditions}$ before measuring luciferase activity. Basal luciferase activity of the untreated vector control was arbitrarily set to 1 , and other values were normalized to this reference point ( $n=3$ independent experiments). ${ }^{*} p<0.01$ (ANOVA). Data are mean \pm SEM. 


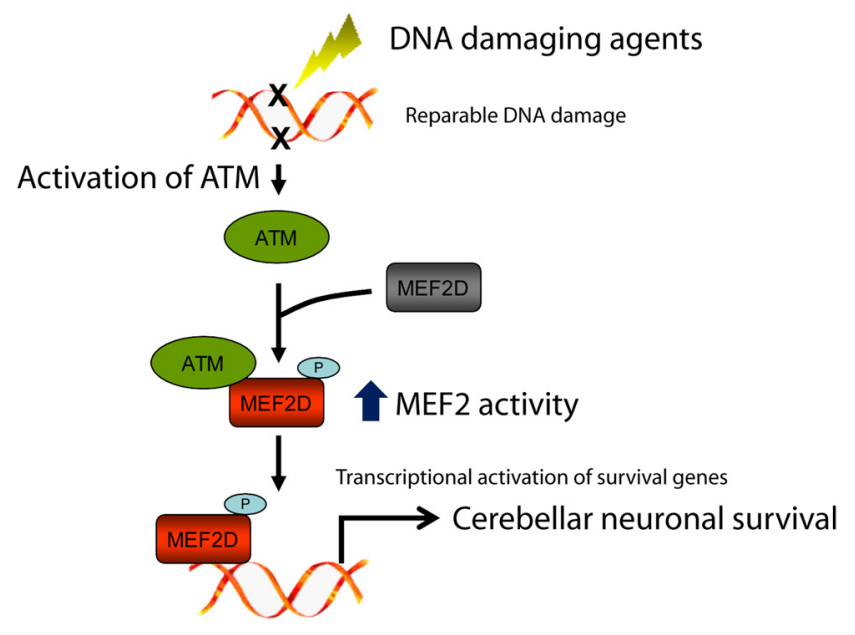

Figure 9. Schema for ATM-dependent phosphorylation/activation of MEF2D enhancing neuronal survival in response to DNA damage. ATM is activated by DSBs resulting from DNAdamaging agents. In the face of reparable DNA damage, activation of ATM leads to (1) formation of an ATM-MEF2D complex and (2) resulting phosphorylation/activation of MEF2. Potentiation of MEF2 activity via ATM phosphorylation promotes cell survival after DNA damage.

significantly elevated in wt mice after irradiation, but not in Mef $2 d^{-1-}$ mice (Fig. $8 A, B$ ). Thus, Bcl-xL may be a target gene of $\mathrm{MEF} 2 \mathrm{D}$ in a prosurvival pathway in response to DNA damage.

Next, we studied the effect of phosphomimetic MEF2D mutants on Bcl-xL promoter activity in Mef $2 d^{-1-}$ cerebellar granule cells. Cells were cotransfected with two reporter constructs, Bcl-xL-luc and Renilla, plus wt MEF2D, nonphosphorylatable MEF2D mutant (T259A/S275A/S294A/S314A), phosphomimetic MEF2D mutant (T259D/S275D/S294D/S314D), or pcDNA3 vector control. The transfected cells were exposed to IR or control (untreated) conditions before measuring luciferase activity. Similar to our findings on MEF2 reporter activity, we found that Bcl-xL promoter activity was elevated in cells expressing the phosphomimetic MEF2D mutant, regardless of irradiation. In contrast, the $\mathrm{Bcl}-\mathrm{xL}$ promoter was not activated in cells expressing the nonphosphorylatable MEF2D mutant (Fig. 8C). Together, these results are consistent with the notion that MEF2D can increase $\mathrm{Bcl}-\mathrm{xL}$ promoter activity. Thus, MEF2D may regulate $\mathrm{Bcl}-\mathrm{xL}$ for a prosurvival pathway in response to DNA damage.

\section{Discussion}

In the present study, we identify an important missing link in the neurodegenerative etiology of AT. For the first time, our studies indicate that MEF2D acts as an ATM effector. This pathway may be a contributing factor to neurodegeneration in AT in which ATM is dysfunctional and cannot therefore activate MEF2Dinduced cerebellar neuron survival. We show that normally ATM associates with MEF2D to activate it via phosphorylation, thus promoting neuronal survival of cerebellar neurons in response to DNA damage (Fig. 9). Previously, p53 was a known target of ATM and was thought to be involved in cell death/survival (McKinnon, 2004). Our new work suggests that another survival pathway, involving the MEF2 family of transcription factors, is also important. Indeed, the predominance of MEF2D in the cerebellum may explain, at least in part, the vulnerability of this brain region in AT. These findings indicate that MEF2D is a DNA damage-responsive protein that participates in DNA damage repair in cerebellar neurons, a completely novel role for this transcription factor. Importantly, this ATM-MEF2D signaling pathway may also have therapeutic implications for promoting survival of cerebellar granule cells in the brains of AT patients (e.g., by using small molecules that enhance MEF2 activity) (Schneider et al., 2008).

Both ATM and ATR display a preference for phosphorylating SQ/TQ motifs in their substrates (Kim et al., 1999; Traven and Heierhorst, 2005; Shiloh, 2006). ATR is predominantly activated by UV light and stalled replication forks, whereas ATM is specifically activated by DSBs of DNA, as seen after irradiation, etoposide, or oxidative stress (Abraham, 2001; Shiloh, 2006). In contrast, treatment with the ATP-competitive kinase inhibitor, staurosporine, does not activate ATM or affect the phosphorylation status of ATM-dependent substrates (Kamer et al., 2005). We show here that DNA-damaging agents, such as IR and etoposide, trigger MEF2D phosphorylation. Moreover, MEF2D phosphorylation only increased after etoposide exposure in wt-ATM cells but not in ATM-deficient cells. These results suggest that ATM mediates MEF2D phosphorylation in response to DSBs in DNA.

Furthermore, in the present study, RNA interferencemediated knockdown experiments in cerebellar granule cells indicate that endogenous MEF2D significantly contributes to neuronal survival after etoposide exposure. Additionally, we found that replacement of endogenous MEF2D with shRNAresistant phosphomimetic MEF2D mutant (but not nonphosphorylatable MEF2D mutant) protected neurons from cell death after DNA damage. These results are consistent with the notion that ATM-mediated phosphorylation/activation of MEF2D induces a prosurvival signal in cerebellar neurons in response to DNA damage and can thus prevent the neurons from dying. This fact may provide a therapeutic window of opportunity for DNA repair pathways to correct damage and avert neuronal demise. In contrast, neurons with defects in the ATM-MEF2D survival pathway are more vulnerable to cell death after DNA damage, which can be triggered by exogenous agents or ROS (Guo et al., 2010). In support of our conclusions, a recent study showed that inactivation of MEF2 by HDAC4 in $\mathrm{Atm}^{-1-}$ mice may alter neuronal gene expression and contribute to neurodegeneration in the cerebellum (Li et al., 2012).

Defective DNA damage signaling has been shown to contribute to neuronal loss in the cerebellum and cerebral cortex in several human neurodegenerative disorders (McKinnon, 2004; Barzilai et al., 2008). Patients with AT exhibit persistent oxidative stress and reduced antioxidant capacity, and brains from Atm knock-out mice show enhanced production of ROS and increased markers of oxidative stress (Reichenbach et al., 2002; Stern et al., 2002). Mice deficient in ATM interactor (ATMIN) have also been shown to exhibit increased susceptibility to oxidative DNA damage (Kanu et al., 2010). In the present study, we observed that Mef $2 d^{-1-}$ mutant mice were highly sensitive to DNA damage after irradiation. Collectively, our results suggest that an impaired response to DNA damage, increased oxidative stress, and failure of the prosurvival ATM-MEF2D signaling pathway may compromise neuronal survival in the cerebellum and thus contribute to progressive neurodegeneration in AT. Moreover, we identified Bcl-xL, an antiapoptotic protein of the Bcl-2 family (Boise et al., 1993; Frankowski et al., 1995; GonzálezGarcía et al., 1995; Chen et al., 1997), as a potential target of the ATM-MEF2D pathway. Accordingly, we found that expression of a phosphomimetic MEF2D mutant can increase Bcl-xL promoter activity in Mef2 $d^{-1-}$ cerebellar granule cells (Fig. 8C). Additionally, several other MEF2 target genes are known to contribute to neuronal survival and synaptic plasticity, such as 
brain-derived neurotrophic factor $(B D N F)$, the orphan steroid receptor Nur77, and the activity-regulated cytoskeletalassociated protein Arc (Flavell et al., 2006; Flavell and Greenberg, 2008; Pulipparacharuvil et al., 2008). A recent study suggests that MEF2D directly regulates mitochondrial DNA-encoded NADH dehydrogenase 6, which is an essential component of complex I enzyme in the oxidative phosphorylation system (She et al., 2011). Dysregulation of this pathway may also contribute to neurodegeneration. Thus, the effects of MEF2D phosphorylation by ATM on neuronal survival may reflect the regulation of several target genes.

In conclusion, we present evidence that phosphorylation of MEF2D by ATM is an important molecular event that regulates neuronal survival in the cerebellum in response to DNA damage and that dysregulation of MEF2D phosphorylation by ATM in AT brains could contribute to the cerebellar damage observed in this disorder. Additionally, because normal aged mice, and presumably humans, display increasing DNA damage (Garinis et al., 2008), the newly discovered ATM-MEF2 pathway described here may also be important in neuronal survival during normal aging.

\section{References}

Abraham RT (2001) Cell cycle checkpoint signaling through the ATM and ATR kinases. Genes Dev 15:2177-2196. CrossRef Medline

Bakkenist CJ, Kastan MB (2003) DNA damage activates ATM through intermolecular autophosphorylation and dimer dissociation. Nature 42: 499-506. CrossRef Medline

Barlow C, Hirotsune S, Paylor R, Liyanage M, Eckhaus M, Collins F, Shiloh Y, Crawley JN, Ried T, Tagle D, Wynshaw-Boris A (1996) Atm-deficient mice: a paradigm of ataxia telangiectasia. Cell 86:159-171. CrossRef Medline

Barzilai A, Rotman G, Shiloh Y (2002) ATM deficiency and oxidative stress: a new dimension of defective response to DNA damage. DNA Repair 1:3-25. CrossRef Medline

Barzilai A, Biton S, Shiloh Y (2008) The role of the DNA damage response in neuronal development, organization and maintenance. DNA Repair 7:1010-1027. CrossRef Medline

Biton S, Dar I, Mittelman L, Pereg Y, Barzilai A, Shiloh Y (2006) Nuclear ataxia-telangiectasia mutated (ATM) mediates the cellular response to DNA double strand breaks in human neuron-like cells. J Biol Chem 281: 17482-17491. CrossRef Medline

Boise LH, González-García M, Postema CE, Ding L, Lindsten T, Turka LA, Mao X, Nuñez G, Thompson CB (1993) Bcl-x, a bcl-2-related gene that functions as a dominant regulator of apoptotic cell death. Cell 74:597608. CrossRef Medline

Breitbart RE, Liang CS, Smoot LB, Laheru DA, Mahdavi V, Nadal-Ginard B (1993) A fourth human MEF2 transcription factor, hMEF2D, is an early marker of themyogenic lineage. Development 118:1095-1106. Medline

Brill LM, Motamedchaboki K, Wu S, Wolf DA (2009) Comprehensive proteomic analysis of Schizosaccharomyces pombe by two-dimensional HPLC-tandem mass spectrometry. Methods 48:311-319. CrossRef Medline

Chen J, Graham SH, Nakayama M, Zhu RL, Jin K, Stetler RA, Simon RP (1997) Apoptosis repressor genes Bcl-2 and Bcl-x-long are expressed in the rat brain following global ischemia. J Cereb Blood Flow Metab 17:210. CrossRef Medline

Falck J, Coates J, Jackson SP (2005) Conserved modes of recruitment of ATM, ATR and DNA-PKcs to sites of DNA damage. Nature 434:605-611. CrossRef Medline

Flavell SW, Greenberg ME (2008) Signaling mechanisms linking neuronal activity to gene expression and plasticity of the nervous system. Annu Rev Neurosci 31:563-590. CrossRef Medline

Flavell SW, Cowan CW, Kim TK, Greer PL, Lin Y, Paradis S, Griffith EC, Hu LS, Chen C, Greenberg ME (2006) Activity-dependent regulation of MEF2 transcription factors suppresses excitatory synapse number. Science 311:1008-1012. CrossRef Medline

Frankowski H, Missotten M, Fernandez PA, Martinou I, Michel P, Sadoul R., Martinou JC (1995) Function and expression of the Bcl-x gene in the developing and adult nervous system. Neuroreport 6:1917-1921. CrossRef Medline
Garinis GA, van der Horst GT, Vijg J, Hoeijmakers JH (2008) DNA damage and ageing: new-age ideas for an age-old problem. Nat Cell Biol 10:12411247. CrossRef Medline

Gaudilliere B, Shi Y, Bonni A (2002) RNA interference reveals a requirement for myocyte enhancer factor $2 \mathrm{~A}$ in activity-dependent neuronal survival. J Biol Chem 277:46442-46446. CrossRef Medline

González-García M, García I, Ding L, O’Shea S, Boise LH, Thompson CB, Núñez G (1995) Bclx is expressed in embryonic and postnatal neural tissues and functions to prevent neuronal cell death. Proc Natl Acad Sci U S A 92:4304-4308. CrossRef Medline

Grillot DA, González-García M, Ekhterae D, Duan L, Inohara N, Ohta S, Seldin MF, Nuñez G (1997) Genomic organization, promoter region analysis, and chromosome localization of the mouse bcl-x gene. J Immunol 158:4750-4757. Medline

Guo Z, Kozlov S, Lavin MF, Person MD, Paull TT (2010) ATM activation by oxidative stress. Science 330:517-521. CrossRef Medline

Gupta S, Campbell D, Dérijard B, Davis RJ (1995) Transcription factor ATF2 regulation by the JNK signal transduction pathway. Science 267: 389-393. CrossRef Medline

Han J, Jiang Y, Li Z, Kravchenko VV, Ulevitch RJ (1997) Activation of the transcription factor MEF2C by the MAP kinase p38 in inflammation. Nature 386:296-299. CrossRef Medline

Hickson I, Zhao Y, Richardson CJ, Green SJ, Martin NM, Orr AI, Reaper PM, Jackson SP, Curtin NJ, Smith GC (2004) Identification and characterization of a novel and specific inhibitor of the ataxia-telangiectasia mutated kinase ATM. Cancer Res 64:9152-9159. CrossRef Medline

Ikeshima H, Imai S, Shimoda K, Hata J, Takano T (1995) Expression of a MADS box gene, MEF2D, in neurons of the mouse central nervous system: implication of its binary function in myogenic and neurogenic cell lineages. Neurosci Lett 200:117-120. CrossRef Medline

Kamer I, Sarig R, Zaltsman Y, Niv H, Oberkovitz G, Regev L, Haimovich G, Lerenthal Y, Marcellus RC, Gross A (2005) Proapoptotic BID is an ATM effector in the DNA-damage response. Cell 122:593-603. CrossRef Medline

Kanu N, Penicud K, Hristova M, Wong B, Irvine E, Plattner F, Raivich G, Behrens A (2010) The ATM cofactor ATMIN protects against oxidative stress and accumulation of DNA damage in the aging brain. J Biol Chem 285:38534-38542. CrossRef Medline

Khanna KK, Jackson SP (2001) DNA double-strand breaks: signaling, repair and the cancer connection. Nat Genet 27:247-254. CrossRef Medline

Khanna KK, Lavin MF, Jackson SP, Mulhern TD (2001) ATM, a central controller of cellular responses to DNA damage. Cell Death Differ 8:1052-1065. CrossRef Medline

Kim ST, Lim DS, Canman CE, Kastan MB (1999) Substrate specificities and identification of putative substrates of ATM kinase family members. J Biol Chem 274:37538-37543. CrossRef Medline

Kim Y, Phan D, van Rooij E, Wang DZ, McAnally J, Qi X, Richardson JA, Hill JA, Bassel-Duby R, Olson EN (2008) The MEF2D transcription factor mediates stress-dependent cardiac remodeling in mice. J Clin Invest 118: 124-132. CrossRef Medline

Kozlov SV, Graham ME, Peng C, Chen P, Robinson PJ, Lavin MF (2006) Involvement of novel autophosphorylation sites in ATM activation. EMBO J 25:3504-3514. CrossRef Medline

Lavin MF, Gueven N, Bottle S, Gatti RA (2007) Current and potential therapeutic strategies for the treatment of ataxia-telangiectasia. Br Med Bull 81:129-147. CrossRef Medline

Leifer D, Krainc D, Yu YT, McDermott J, Breitbart RE, Heng J, Neve RL, Kosofsky B, Nadal-Ginard B, Lipton SA (1993) MEF2C, a MADS/ MEF2-family transcription factor expressed in a laminar distribution in cerebral cortex. Proc Natl Acad Sci U S A 90:1546-1550. CrossRef Medline

Levi G, Aloisi F, Ciotti MT, Gallo V (1984) Autoradiographic localization and depolarization-induced release of acidic amino acids in differentiating cerebellar granule cell cultures. Brain Res 290:77-86. CrossRef Medline

Li J, Chen J, Ricupero CL, Hart RP, Schwartz MS, Kusnecov A, Herrup K (2012) Nuclear accumulation of HDAC4 in ATM deficiency promotes neurodegeneration in ataxia telangiectasia. Nat Med 18:783-790. CrossRef Medline

Li M, Linseman DA, Allen MP, Meintzer MK, Wang X, Laessig T, Wierman ME, Heidenreich KA (2001) Myocyte enhancer factor 2A and 2D undergo phosphorylation and caspase-mediated degradation during apo- 
ptosis of rat cerebellar granule neurons. J Neurosci 21:6544-6552. Medline

Li Z, McKercher SR, Cui J, Nie Z, Soussou W, Roberts AJ, Sallmen T, Lipton JH, Talantova M, Okamoto S, Lipton SA (2008) Myocyte enhancer factor $2 \mathrm{C}$ as a neurogenic and antiapoptotic transcription factor in murine embryonic stem cells. J Neurosci 28:6557-6568. CrossRef Medline

Lin X, Shah S, Bulleit RF (1996) The expression of MEF2 genes is implicated in CNS neuronal differentiation. Brain Res. Mol Brain Res 42:307-316. CrossRef Medline

Liu T, Hannafon B, Gill L, Kelly W, Benbrook D (2007) Flex-Hets differentially induce apoptosis in cancer over normal cells by directly targeting mitochondria. Mol Cancer Ther 6:1814-1822. CrossRef Medline

Livak KJ, Schmittgen TD (2001) Analysis of relative gene expression data using real-time quantitative PCR and the 2(-Delta Delta C(T)) Method. Methods 25:402-408. CrossRef Medline

Lyons GE, Micales BK, Schwarz J, Martin JF, Olson EN (1995) Expression of mef2 genes in the mouse central nervous system suggests a role in neuronal maturation. J Neurosci 15:5727-5738. Medline

Ma L, Tao Y, Duran A, Llado V, Galvez A, Barger JF, Castilla EA, Chen J, Yajima T, Porollo A, Medvedovic M, Brill LM, Plas DR, Riedl SJ, Leitges M, Diaz-Meco MT, Richardson AD, Moscat J (2013) Control of nutrient stress-induced metabolic reprogramming by $\mathrm{PKC} \zeta$ in tumorigenesis. Cell 152:599-611. CrossRef Medline

McKinnon PJ (2004) ATM and ataxia telangiectasia. EMBO Rep 5:772-776. CrossRef Medline

McKinsey TA, Zhang CL, Olson EN (2002) MEF2: a calcium-dependent regulator of cell division, differentiation and death. Trends Biochem Sci 27:40-47. CrossRef Medline

Naya FJ, Olson E (1999) MEF2: a transcriptional target for signaling pathways controlling skeletal muscle growth and differentiation. Curr Opin Cell Biol 11:683-688. CrossRef Medline

Okamoto S, Krainc D, Sherman K, Lipton SA (2000) Antiapoptotic role of the p38 mitogen-activated protein kinase-myocyte enhancer factor 2 transcription factor pathway during neuronal differentiation. Proc Natl Acad Sci U S A 20:7561-7566. CrossRef Medline

Okamoto S, Li Z, Ju C, Scholzke MN, Mathews E, Cui J, Salvesen GS, BossyWetzel E, Lipton SA (2002) Dominant-interfering forms of MEF2 generated by caspase cleavage contribute to NMDA-induced neuronal apoptosis. Proc Natl Acad Sci U S A 99:3974-3979. CrossRef Medline

O’Neill T, Dwyer AJ, Ziv Y, Chan DW, Lees-Miller SP, Abraham RH, Lai JH, Hill D, Shiloh Y, Cantley LC, Rathbun GA (2000) Utilization of oriented peptide libraries to identify substrate motifs selected by ATM. J Biol Chem 275:22719-22727. CrossRef Medline

Pulipparacharuvil S, Renthal W, Hale CF, Taniguchi M, Xiao G, Kumar A, Russo SJ, Sikder D, Dewey CM, Davis MM, Greengard P, Nairn AC, Nestler EJ, Cowan CW (2008) Cocaine regulates MEF2 to control synaptic and behavioral plasticity. Neuron 59:621-633. CrossRef Medline

Reichenbach J, Schubert R, Schindler D, Müller K, Böhles H, Zielen S (2002) Elevated oxidative stress in patients with ataxia telangiectasia. Antioxid Redox Signal 4:465-469. CrossRef Medline

Robinson KM, Janes MS, Beckman JS (2008) The selective detection of mitochondrial superoxide by live cell imaging. Nat Protoc 3:941-947. CrossRef Medline
Rotman G, Shiloh Y (1997) Ataxia-telangiectasia: is ATM a sensor of oxidative damage and stress? BioEssays 19:911-917. CrossRef Medline

Rotman G, Shiloh Y (1998) ATM: from gene to function. Hum Mol Genet 7:1555-1563. CrossRef Medline

Schmittgen TD, Livak KJ (2008) Analyzing real-time PCR data by the comparative C(T) method. Nat Protoc 3:1101-1108. CrossRef Medline

Schneider JW, Gao Z, Li S, Farooqi M, Tang TS, Bezprozvanny I, Frantz DE, Hsieh J (2008) Small-molecule activation of neuronal cell fate. Nat Chem Biol 4:408-410. CrossRef Medline

Shalizi A, Lehtinen M, Gaudilliere B, Donovan N, Han J, Konishi Y, Bonni A (2003) Characterization of a neurotrophin signaling mechanism that mediates neuron survival in a temporally specific pattern. J Neurosci 23:7326-7336. Medline

Shalizi A, Gaudillière B, Yuan Z, Stegmüller J, Shirogane T, Ge Q, Tan Y, Schulman B, Harper JW, Bonni A (2006) A calcium-regulated MEF2 sumoylation switch controls postsynaptic differentiation. Science 311: 1012-1017. CrossRef Medline

She H, Yang Q, Shepherd K, Smith Y, Miller G, Testa C, Mao Z (2011) Direct regulation of complex I by mitochondrial MEF2D is disrupted in a mouse model of Parkinson disease and in human patients. J Clin Invest 121:930-940. CrossRef Medline

Shiloh Y (2003) ATM and related protein kinases: safeguarding genome integrity. Nat Rev Cancer 3:155-168. CrossRef Medline

Shiloh Y (2006) The ATM-mediated DNA-damage response: taking shape. Trends Biochem Sci 31:402-410. CrossRef Medline

Stern N, Hochman A, Zemach N, Weizman N, Hammel I, Shiloh Y, Rotman G, Barzilai A (2002) Accumulation of DNA damage and reduced levels of nicotine adenine dinucleotide in the brains of Atm-deficient mice. J Biol Chem 277:602-608. CrossRef Medline

Swaney DL, McAlister GC, Coon JJ (2008) Decision tree-driven tandem mass spectrometry for shotgun proteomics. Nat Methods 5:959-964. CrossRef Medline

Syka JE, Coon JJ, Schroeder MJ, Shabanowitz J, Hunt DF (2004) Peptide and protein sequence analysis by electron transfer dissociation mass spectrometry. Proc Natl Acad Sci U S A 101:9528-9533. CrossRef Medline

Traven A, Heierhorst J (2005) SQ/TQ cluster domains: concentrated ATM/ ATR kinase phosphorylation site regions in DNA-damage-response proteins. Bioessays 27:397-407. CrossRef Medline

Uziel T, Lerenthal Y, Moyal L, Andegeko Y, Mittelman L, Shiloh Y (2003) Requirement of the MRN complex for ATM activation by DNA damage. EMBO J 22:5612-5621. CrossRef Medline

Wilson DM 3rd, Bianchi C (1999) Improved immunodetection of nuclear antigens after sodium dodecyl sulfate treatment of formaldehyde-fixed cells. J Histochem Cytochem 47:1095-1100. CrossRef Medline

Wu ZH, Shi Y, Tibbetts RS, Miyamoto S (2006) Molecular linkage between the kinase ATM and NF-kappaB signaling in response to genotoxic stimuli. Science 311:1141-1146. CrossRef Medline

Zinkel SS, Hurov KE, Ong C, Abtahi FM, Gross A, Korsmeyer SJ (2005) A role for proapoptotic BID in the DNA-damage response. Cell 122:579_ 591. CrossRef Medline

Ziv Y, Banin S, Lim DS, Canman CE, Kastan MB, Shiloh Y (2000) Expression and assay of recombinant ATM. Methods Mol Biol 99:99-108. CrossRef Medline 